\title{
Developing Neolignans as Proangiogenic Agents: Stereoselective Total Syntheses and Preliminary Biological Evaluations of the Four Guaiacylglycerol 8-O-4'-Coniferyl Ethers
}

\author{
Joshua N. Buckler, ${ }^{\dagger}$ Martin G. Banwell, ${ }^{* \dagger}{ }^{\dagger}$ Farzaneh Kordbacheh, ${ }^{\ddagger}$ Christopher R. Parish, ${ }^{\ddagger}$
} Fernando S. Santiago, ${ }^{\S}$ and Levon M. Khachigian ${ }^{\S}$

${ }^{\dagger}$ Research School of Chemistry, Institute of Advanced Studies and ${ }^{\ddagger}$ The John Curtin School of Medical Research, Institute of Advanced Studies, The Australian National University, Canberra, ACT 2601, Australia

${ }^{\S}$ School of Medical Sciences, Faculty of Medicine, The University of New South Wales, Sydney, NSW 2052, Australia

Supporting Information

ABSTRACT: Stereoselective total syntheses of the four stereoisomeric forms of guaiacylglycerol 8-O-4'-coniferyl ether, viz., compounds 1 , ent-1, 2, and ent-2, have been established. The key step involves an Evans/Seebach auxiliarycontrolled and syn-selective aldol process followed, in the reaction sequences leading to the anti-compounds, by a Mitsunobu reaction involving a benzylic alcohol residue. The proangiogenic properties of the synthetic materials were evaluated in a human microvascular endothelial cell tubule formation assay, thus revealing that they are all active, with the 8S-configured compounds 1 and 2 being the most potent.

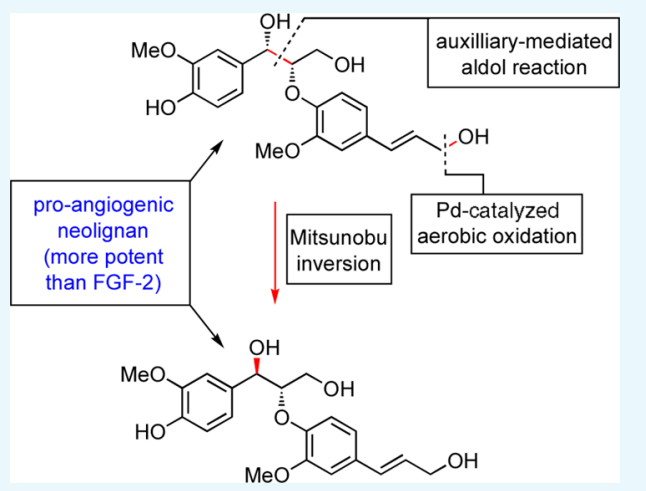

\section{INTRODUCTION}

Compounds that promote the formation of new blood vessels from existing endothelia are described as proangiogenic and could be beneficial in promoting wound healing, treating burns, and the revascularization of ischemic tissues encountered in stroke victims and those suffering from cardiac disorders. ${ }^{1}$ Screening plant extracts for such properties is an emerging area of interest and the rat aortic ring model and related assays have proven useful in identifying natural products that can modulate angiogenesis. $^{2,3}$ By such means, various extracts of soybean (particularly the xylem sap) were evaluated recently, and two proangiogenic principals were isolated. ${ }^{3}$ Although only small quantities of these materials were obtained, ${ }^{1} \mathrm{H}$ and ${ }^{13} \mathrm{C}$ NMR spectroscopic as well as mass spectral analyses suggested that these are one or other of the neolignans $\mathbf{1}$ or ent-1 and $\mathbf{2}$ or ent2. ${ }^{3}$ The racemic forms of these compounds have previously been isolated from various other plant sources and shown to exhibit a range of biological effects. ${ }^{4}$ They are almost certainly produced in vivo through peroxidase-mediated radical coupling of coniferyl alcohol, and optically enriched forms of them (but of undefined absolute stereochemistry) have been generated by enzymatic dehydrogenative coupling of this monomer using cell-free extracts of a producing organism. ${ }^{5}$

Given the very small amounts of these compounds available from natural sources, the seasonal variations in their yields, and the lack of information regarding their stereostructures (and, in many instances, their optical purities), unambiguous syntheses of the guaiacylglycerol $8-O-4^{\prime}$-coniferyl ethers $\mathbf{1}$, ent-1, 2, and ent-2 were sought in an effort to clarify matters. Herein, we detail the total syntheses of each of these four stereoisomeric 8$O-4^{\prime}$-linked neolignans ${ }^{6,7}$ and report on their proangiogenic properties (Figure 1).

\section{RESULTS AND DISCUSSION}

Syntheses of the Racemic Forms of Compounds 1 and 2. Although many neolignans have been the subject of synthetic studies, ${ }^{8}$ enantioselective approaches to $8-O-4^{\prime}$ linked systems, as required in accessing the compounds targeted here, have received only modest attention. ${ }^{9,10}$ Our first approach to compounds 1, ent-1, 2, and ent-2 is shown in Scheme 1, and in this we sought, inter alia, to exploit key elements of Ley's asymmetric synthesis of the $8-O-4^{\prime}$ neolignan polysphorin. ${ }^{9 a}$ This started with the conversion, by conventional means, of commercially available ferulic acid (3) over four steps into bismethoxymethyl (MOM) ether 4 (79\%) (see Experimental Section for details). Asymmetric dihydroxylation of the olefinic residue within compound 4 using $\mathrm{AD}$-mix- $\alpha$ and methanesulfonamide afforded the diol 5 (78\%), the configuration of which was assigned using the Sharpless "mnemonic". ${ }^{11}$ Although the enantiomeric excess (ee) of this oxidation product was not established, the fact that it was optically

Received: September 29, 2017

Accepted: October 9, 2017

Published: October 30, 2017 
<smiles>COc1cc([C@@H](O)[C@@H](O)CO)ccc1O[C@H](O)[C@@H](C)CO</smiles>

1<smiles>COc1cc([C@@H](O)[C@H](CO)Oc2ccc(/C=C/CO)cc2OC)ccc1O</smiles>

ent-1<smiles>COc1cc([C@@H](O)[C@@H](CO)Oc2ccc(/C=C/CO)cc2OC)ccc1O</smiles>

2<smiles>COc1cc([C@@H](O)[C@H](CO)Oc2ccc(/C=C/CO)cc2OC)ccc1O</smiles>

ent-2

Figure 1. Structures of the four stereoisomeric forms, 1, ent-1, 2, and ent-2, of guaiacylglycerol 8-O-4'-coniferyl ether targeted for synthesis.

Scheme 1. Synthesis of Compounds $( \pm)-1$ and $( \pm)-2$<smiles>COc1cc(/C=C/C(=O)O)ccc1O</smiles>

3

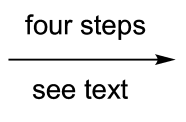<smiles>COCC=Cc1ccc(OC)c(OC)c1</smiles><smiles>COC[C@H](O)[C@@H](O)c1ccc(OC)c(OC)c1</smiles>

DDQ $\mathrm{C}_{6} \mathrm{H}_{6}$ $86 \%$<smiles>COC[C@H](O)C(=O)c1ccc(OC)c(OC)c1</smiles><smiles>COc1cc(C(=O)[C@H](CO)Oc2ccc(/C=C/C=O)cc2OC)ccc1O</smiles>

10

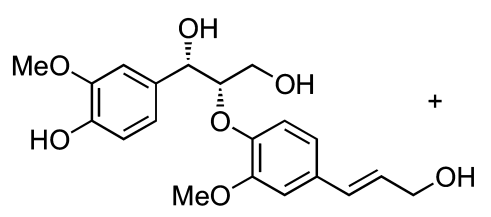

$( \pm)-1$<smiles>COc1cc([C@@H](O)C(CO)Oc2ccc(/C=C/CO)cc2OC)ccc1O</smiles>

(士)-2 active $\left\{[\alpha]_{\mathrm{D}}+10.7\left(c=1.02, \mathrm{CHCl}_{3}\right)\right\}$ encouraged us to continue exploring the reaction sequence, the next step of which involved selective oxidation of the benzylic hydroxyl group within compound 5 using 2,3-dichloro-5,6-dicyano-1,4benzoquinone (DDQ) under ultrasonication conditions. ${ }^{12}$ By such means, the acyloin $6(86 \%)$ was obtained and the 
associated hydroxyl group was reacted with $p$-toluenesulfonic anhydride in the presence of pyridine, thus giving the optically active ester 7 in $93 \%$ yield. Although treating this last compound with coniferyl aldehyde (8) in the presence of cesium carbonate and 18 -crown-6 (18-C-6) led to the formation of the anticipated $8-0-4^{\prime}$-linked ether 9 (47\%), this proved to be an optically inactive material, thus suggesting racemization of substrate 7 and/or the product had occurred under the reaction conditions. ${ }^{1}$ Despite this, the completion of the synthetic pathway was pursued because of the capacity it provided to deliver the racemic forms of the target compounds (materials that would prove useful in establishing the enantiomeric excesses of their enantiomerically enriched congeners). So, compound 9 was treated with a trace of concentrated $\mathrm{HCl}$ in isopropanol, thus effecting cleavage of the MOM-ether residues, and thereby affording the dihydroxyderivative 10 (76\%). The required 2 -fold reduction of the ketoaldehyde 10 was best effected using polymer-supported borohydride $^{9 a}$ and, in a presumably sterically driven process, this gave a ca. 7:1 mixture of the diastereoisomeric syn- and anti-compounds $( \pm)-1$ and ( \pm )-2, respectively, in $87 \%$ combined yield. These could be separated from one another using reverse phase high-performance liquid chromatography (HPLC) and the spectral data derived from each were in complete accord with those reported earlier ${ }^{4 e, 1}$ for the natural products (see Table 1 for relevant comparisons of the ${ }^{13} \mathrm{C}$ NMR data sets).

Although each of the synthetically derived compounds $( \pm)-1$ and $( \pm)-2$ could be separated into their constituent enantiomers using chiral HPLC techniques, the equivalent analysis of the soybean-derived natural products could not be carried out due to their decomposition on prolonged ( $>12$ months) standing (as a crude extract). That said, when samples of these compounds have been isolated from other plant sources, they tend to be obtained as racemates or, at best, enantiomerically enriched (but certainly not homochiral) materials. ${ }^{\text {a }}$

Chiral Auxiliary-Controlled Syntheses of Homochiral Compounds 1 and ent-1. The synthetic route successfully employed in obtaining neolignan ent-1 is shown in Scheme 2 and involved, as the key feature, an Evans' aldol reaction ${ }^{13}$ utilizing the readily available L-valine (11)-derived chiral auxiliary 12 introduced by Seebach. ${ }^{14}$ This was coupled with the eugenol (13)-derived and readily available $\alpha$-aryloxyacetic acid 14 (85\%) through its conversion into the corresponding acid chloride and reaction of this with the anion derived from deprotonation of the 2-oxazolidinone 12 using $n$-butyl lithium. Compound 15 (93\%) so formed was then converted, on treatment with dibutylboron triflate in the presence of Hünig's base, ${ }^{14 a}$ into the corresponding boron enolate that reacted stereoselectively with aldehyde 16 embodying a tert-butyldimethylsilyl (TBDMS)-protected phenol residue. The auxiliary associated with the aldol product so-formed was cleaved using lithium borohydride/methanol, thus affording the $1^{\circ}$-alcohol 17 (76\% from 15) as a single diastereoisomer and in optically active form $\left\{[\alpha]_{\mathrm{D}}=-63.3\left(c=0.8, \mathrm{CHCl}_{3}\right)\right\}$. The illustrated structure was initially assigned to compound $\mathbf{1 7}$ on the basis of the well-established syn-selective outcomes of Evans' aldol reactions ${ }^{9 \mathrm{~h}, 13,14}$ involving the types of auxiliaries used here, but eventually it was confirmed through chemical correlation studies (see below). Aerobic and palladium-catalyzed acetoxylation of compound $\mathbf{1 7}$ using a procedure reported by Stahl et al. ${ }^{15}$ and employing 4,5-diazafluorenone as ligand then afforded
Table 1. Comparison of the ${ }^{13} \mathrm{C}$ NMR Chemical Shift Data Recorded for Synthetically Derived Compounds $( \pm)-1$ and $( \pm)-2$ with Those Reported for the Naturally Derived threoand erythro-Guaiacylglycerol 8-O-4' -Coniferyl Ethers (threoGCCE and erythro-GCCE, Respectively)

$\begin{array}{cccccc}\begin{array}{c}{ }^{13} \mathrm{C} \text { NMR } \\ \text { data for } \\ \text { compound } \\ ( \pm)-1\left(\delta_{\mathrm{C}}\right)^{a}\end{array} & \begin{array}{c}{ }^{13} \mathrm{C} \text { NMR } \\ \text { data for } \\ \text { threo-GCCE }\end{array} & \begin{array}{c}\left.{ }_{\mathrm{C}}\right)^{b} \\ 151.6\end{array} & \begin{array}{c}{ }^{13} \mathrm{C} \text { NMR } \\ \text { data for } \\ \text { compound } \\ ( \pm)-2\left(\delta_{\mathrm{C}}\right)^{c}\end{array} & \begin{array}{c}{ }^{13} \mathrm{C} \text { NMR } \\ \text { data for } \\ \text { erythro-GCCE } \\ \left(\delta_{\mathrm{C}}\right)^{d}\end{array} & \Delta \delta \\ 149.1 & 149.3 & -0.2 & 151.9 & 151.8 & +0.1 \\ 148.8 & 148.8 & 0.0 & 148.9 & 149.0 & -0.1 \\ 147.1 & 147.2 & -0.1 & 148.7 & 148.6 & +0.1 \\ 133.7 & 133.8 & -0.1 & 134.1 & 147.2 & -0.2 \\ 133.1 & 133.2 & -0.1 & 133.0 & 134.2 & -0.1 \\ 131.4 & 131.5 & -0.1 & 131.4^{e} & 133.1 & -0.1 \\ 128.6 & 128.7 & -0.1 & 128.5 & 128.8 & +0.6^{f} \\ 120.8 & 120.9 & -0.1 & 121.0 & 121.1 & -0.0 \\ 120.7 & 120.8 & +0.1 & 120.7 & 120.8 & -0.1 \\ 118.6 & 118.9 & -0.3 & 118.9 & 119.0 & -0.1 \\ 115.8 & 115.9 & -0.1 & 115.7 & 115.7 & 0.0 \\ 111.7 & 111.8 & -0.1 & 111.9 & 111.9 & 0.0 \\ 111.2 & 111.3 & -0.1 & 111.4^{g} & 110.8 & +0.6^{f} \\ 87.0 & 87.2 & -0.2 & 86.2 & 86.3 & -0.1 \\ 74.0 & 74.1 & -0.1 & 74.1 & 74.2 & -0.1 \\ 63.7 & 63.8 & -0.1 & 63.8 & 63.9 & -0.1 \\ 61.9 & 62.0 & -0.1 & 62.2 & 62.3 & -0.1 \\ 56.6 & 56.6 & 0.0 & 56.5 & 56.6 & -0.1 \\ 56.3 & 56.4 & -0.1 & 56.4 & 56.6 & -0.2\end{array}$

${ }^{a}$ Spectrum recorded in $\mathrm{CD}_{3} \mathrm{OD}$ at $100 \mathrm{MHz} .{ }^{b}$ Data obtained from Woo, ${ }^{4 \mathrm{l}}$ spectrum recorded in $\mathrm{CD}_{3} \mathrm{OD}$ at $125 \mathrm{MHz}$. ${ }^{c}$ Spectrum recorded in $\mathrm{CD}_{3} \mathrm{OD}$ at $100 \mathrm{MHz}$. ${ }^{d}$ Data obtained from $\mathrm{Li}^{4 \mathrm{e}}$ spectrum recorded in $\mathrm{CD}_{3} \mathrm{OD}$ at $100 \mathrm{MHz}$. ${ }^{e}$ Lourith et al. report ${ }^{10}$ a chemical shift of 131.5 for the resonance due to this carbon. ${ }^{f}$ We attribute these differences to variations in the $\mathrm{pH}$ of the media in which the spectra were recorded. ${ }^{g}$ Lourith et al. report ${ }^{10}$ a chemical shift of 111.4 for the resonance due to this carbon.

ester 18 in $48 \%$ yield and exclusively in the E-isomeric form. Cleavage of both the acetate and silyl ether residues associated with compound $\mathbf{1 8}$ was accomplished using potassium carbonate in methanol, thus giving the target neolignan ent-1 in $79 \%$ yield.

All of the mass spectral as well as the NMR and IR spectroscopic data acquired on compound ent-1 matched those derived from the corresponding racemate $[( \pm)-1]$, and the specific rotation determined for the optically active material was -36.7 ( $c=0.9$, methanol). Chiral HPLC analysis of compound ent-1 established that it was of $>99 \%$ enantiomeric excess and represents the less mobile component of the racemate $( \pm)-\mathbf{1}$.

The synthesis of compound $\mathbf{1}$ was readily achieved following the reaction scheme shown above but using the auxilliary ent-12 derived from $\mathrm{D}$-valine (ent-11). Although all of the spectral data recorded on neolignan $\mathbf{1}$ matched those reported for its enantiomer, the specific rotation of this material was of similar magnitude but opposite sign $\left\{[\alpha]_{\mathrm{D}}=+32.4(c=0.2\right.$, methanol)\}. Chiral HPLC analysis of compound 1 established that it had been obtained in ca. $90 \%$ ee and represents the more mobile component of the racemate $( \pm)-1$ obtained earlier.

The synthesis of the anti-compound ent-2 is shown in Scheme 3 and involved, in the opening stages, selective monoprotection of the $1^{\circ}$-alcohol residue within compound 17 followed by cleavage of the associated phenolic TBDMS ether. 
Scheme 2. Synthesis of Compound ent-1

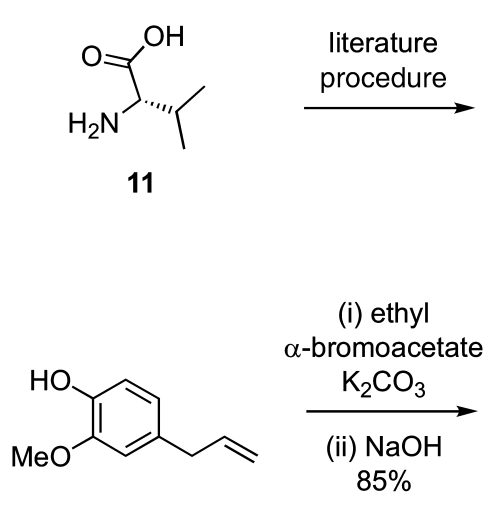

13

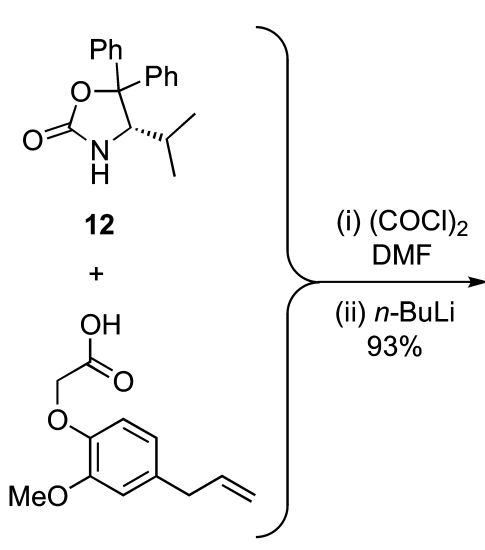

14<smiles>C=CCc1ccc(OCC(=O)N2C(=O)OC(c3ccccc3)(c3ccccc3)[C@H]2C(C)C)c(OC)c1</smiles>

15

$+$<smiles>COc1ccc(C=O)cc1OC</smiles>

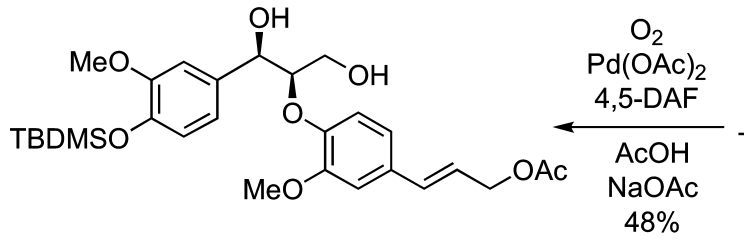

18<smiles>C=CCc1ccc(OC(CO)[C@H](O)c2ccc(OC)c(OC)c2)c(OC)c1</smiles>

17<smiles>COc1cc([C@H](O)[C@H](CO)Oc2ccc(/C=C/CO)cc2OC)ccc1O</smiles>

ent-1<smiles>CC(C)C1NC(=O)OC1(c1ccccc1)c1ccccc1</smiles>

ent-12<smiles>COc1cc([C@@H](O)[C@H](CO)Oc2ccc(/C=C/CO)cc2OC)ccc1O</smiles>

This gave phenol 19 (96\%) that was reacted with $p$ toluenesulfonyl chloride $(p-\mathrm{TsCl})$ in the presence of triethyamine and 4-(N,N-dimethylamino)pyridine (DMAP) to afford ester 20 (87\%). The introduction of the tosyl group was necessary to attenuate the electron-donating properties of the attached aryl oxygen such that this now did not facilitate ionization of activated forms of the benzylic alcohol during the subsequent Mitsunobu reaction. ${ }^{16}$ Consistent with such expectations, when compound $\mathbf{2 0}$ was treated with triphenylphosphine and diethyl azodicarboxylate (DEAD), and using $p$ nitrobenzoic acid as nucleophile, benzoate 21 (84\%) was obtained. Confirmation of the illustrated S-configuration at the PNB-ester bearing center in this product follows from its conversion into the target neolignan ent-2. To such ends, treatment of compound $\mathbf{2 1}$ with sodium hydroxide in tetrahydrofuran (THF)/water afforded the alcohol 22 (74\%) that was itself subjected to allylic oxidation using Stahl's protocol, ${ }^{15}$ thereby affording acetate 23 in $64 \%$ yield.
Treatment of ester $\mathbf{2 3}$ with tetra- $n$-butylammonium fluoride (TBAF) then sodium hydroxide in water/methanol resulted in cleavage of the TBDMS ether, acetate, and tosyl groups such that the targeted neolignan ent- 2 was obtained in $73 \%$ yield. All of the spectral data obtained on this material were consistent with the assigned structure. Chiral HPLC analysis established that it was of $>99 \%$ ee. The specific rotation of this material was $[\alpha]^{20}{ }_{\mathrm{D}}=-8.1(c=1.1$, methanol $)$, and it represents the more mobile component of the racemate $( \pm)-2$.

The synthesis of compound $\mathbf{2}$ was readily achieved following the reaction scheme shown but using compound ent-17 as starting material. Although all of the spectral data recorded on neolignan 2 matched those reported for its enantiomer, the specific rotation of this material was of similar magnitude but opposite sign $\left\{[\alpha]^{20}{ }_{\mathrm{D}}=+7.4(c=0.5\right.$, methanol $\left.)\right\}$. Similarly, chiral HPLC analysis of compound 2 established that it was of $>99 \%$ ee and that it represents the less mobile component of the racemate $( \pm)-2$ obtained as described above. 
Scheme 3. Synthesis of Compound ent-2<smiles>C=CCc1ccc(O[C@H](CO)[C@H](O)c2ccc(O)c(OC(CO)[C@H](O)c3ccc(O)c(OC)c3)c2)c(OC)c1</smiles>

17<smiles>COc1ccc(C(O)C(C[O+]S(C)(=O)=O)Oc2ccc(/C=C/COC(C)=O)cc2OC)cc1OC</smiles>

23
19<smiles>C=CCc1ccc(OC(CO[R16](C)(C)C)[C@H](O)c2ccc(OS(C)(=O)=O)c(OC)c2)c(OC)c1</smiles>

22<smiles>C=CCc1ccc(OC(CO[Sn](C)(C)C)[C@H](O)c2ccc(OC(F)(F)F)c(OC)c2)c(OC)c1</smiles>

20

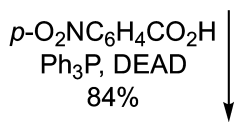

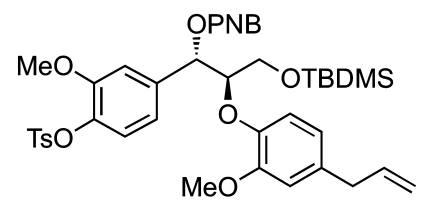

21

$$
\begin{array}{c|c}
\text { (i) TBAF } & \text { (ii) aq. } \mathrm{NaOH} \\
\text { THF } & \begin{array}{c}
\mathrm{MeOH} \\
73 \%
\end{array}
\end{array}
$$<smiles>COc1cc([C@H](O)C(CO)Oc2ccc(/C=C/CO)cc2OC)ccc1O</smiles>

ent-2<smiles>COc1cc([C@H](O)[C@H](CO)Oc2ccc(/C=C/CO)cc2OC)ccc1O</smiles>

2
To this point, the assignments of the illustrated structures to compounds 1, ent-1, 2, and ent-2 are based on the assumption that the pivotal Evans' aldol reactions proceed in the anticipated (syn-selective) manner and that the Mitsunobu reactions take place with inversion of configuration. Further support follows from the recent work of Nair et al., ${ }^{9 k}$ who employed closely related Evans' aldol protocols to prepare compound $\mathbf{2}$ and who undertook certain chemical correlation studies and a single-crystal X-ray analysis to establish the selectivities of their pivotal reaction. The NMR spectroscopic data we acquired on compound 2 matched those reported by Nair. $^{9 k}$

Initial Biological Evaluations of Compounds 1, ent-1, 2, and ent-2. Compounds 1 and 2 as well as their enantiomers, ent-1 and ent-2, respectively, were each examined for their abilities to enhance endothelial cell tubule formation on reconstituted basement membrane matrix (see Figure 2 and the Experimental Section) in an assay widely used to identify proangiogenic and antiangiogenic factors and their underlying mechanism(s) of action. ${ }^{17}$

All four compounds stimulated endothelial cell tubule formation compared with media only, with compounds 1 and 2 being the most active and congener ent- 2 the least active. It is noteworthy that each of these neolignans exhibited significant proangiogenic activity compared with media only, with compound 1 being more active than the fibroblast growth factor 2 (FGF-2) control. ${ }^{18}$ The flavone derivative PD98059, an inhibitor of mitogen-activated protein kinase (MEK1/2) and FGF-2 signaling, suppressed the proangiogenic activity of all of the compounds, which is consistent with the title neolignans acting via this pathway.

\section{CONCLUSIONS}

The work detailed here provides stereochemically unambiguous routes to a quartet of neolignans that display varying degrees of activity as proangiogenic agents. The variation in efficacy as a function of stereochemistry indicates that the S-configuration at C8 (as seen in neolignans 1 and 2) has a positive impact on activity, with compound $\mathbf{1}$ being even more active than the FGF-2 control. To the best of our knowledge, this work represents the first time that a suite of diastereisomerically related neolignans has been identified as proangiogenic agents. As such, it should serve as an important consideration for the development of proangiogenic compounds that might serve as therapeutic agents.

\section{EXPERIMENTAL SECTION}

General Protocols. Unless otherwise specified, proton $\left({ }^{1} \mathrm{H}\right)$ and carbon $\left({ }^{13} \mathrm{C}\right)$ NMR spectra were recorded at room temperature in base-filtered $\mathrm{CDCl}_{3}$ on a Varian spectrometer operating at $400 \mathrm{MHz}$ for proton and $100 \mathrm{MHz}$ for carbon nuclei. The signal due to residual $\mathrm{CHCl}_{3}$ appearing at $\delta_{\mathrm{H}} 7.26$ and the central resonance of the $\mathrm{CDCl}_{3}$ triplet appearing at $\delta_{\mathrm{C}}$ 77.1(6) were used to reference ${ }^{1} \mathrm{H}$ and ${ }^{13} \mathrm{C}$ NMR spectra, 


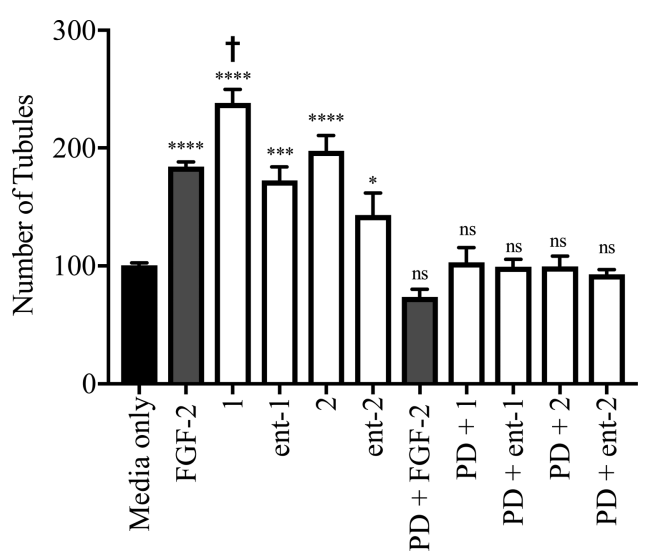

Figure 2. Effect of neolignans 1, ent-1, 2, and ent-2 on tubule formation by human microvascular endothelial cells (HMECs) on reconstituted basement membrane matrix (Matrigel) over a $4 \mathrm{~h}$ period compared with that of media (only) and fibroblast growth factor (FGF)-2 (positive) controls as well as when coadministered with the MEK1/2 inhibitor PD (PD98059). The columns represent the mean of the means of 4 independent experiments with each condition performed in triplicate. Error bars represent the standard error of the mean. Statistical significance was determined by one-way ANOVA and Dunnett's multiple comparisons test (compared with media only, i.e., MCDB131 medium with supplements and $0.2 \%$ fetal bovine serum (FBS)) using GraphPad Prism software, where **** denotes $P<$ 0.0001 , *** denotes $P<0.001$, * denotes $P<0.05$, ns denotes not significant, and $\dagger$ denotes significance at $P<0.01$ between FGF-2 and compound 1. There was no significant difference between FGF-2 and compounds 2 , ent-1, or ent-2.

respectively. ${ }^{1} \mathrm{H}$ NMR data are recorded as follows: chemical shift $(\delta)$ [multiplicity, coupling constant $(\mathrm{s}) J(\mathrm{~Hz})$, relative integral] where multiplicity is defined as: $\mathrm{s}=$ singlet; $\mathrm{d}=$ doublet; $\mathrm{t}=$ triplet; $\mathrm{q}=$ quartet; $\mathrm{m}=$ multiplet or combinations of the above. Infrared spectra $\left(\nu_{\max }\right)$ were recorded on a Fourier transform infrared spectrometer. Samples were analyzed as thin films on $\mathrm{KBr}$ plates or as neat material. Low-resolution electrospray ionization (ESI) mass spectra were recorded on a single quadrupole liquid chromatograph-mass spectrometer, whereas high-resolution measurements were conducted on a time-of-flight instrument. Low- and high-resolution electron ionization (EI) mass spectra were recorded on a magneticsector machine. Melting points were measured on an Optimelt automated melting point system and are uncorrected. Analytical thin layer chromatography was performed on aluminum-backed $0.2 \mathrm{~mm}$ thick silica gel $60 \mathrm{~F}_{254}$ plates as supplied by Merck. Eluted plates were visualized using a $254 \mathrm{~nm}$ UV lamp and/or by treatment with a suitable dip followed by heating. These dips included phosphomolybdic acid/ceric sulfate/sulfuric acid (conc.)/water (37.5 g:7.5 g:37.5 g:720 mL) or potassium permanganate/potassium carbonate $/ 5 \%$ sodium hydroxide aqueous solution/water (3 g:20 g:5 mL:300 mL). Flash chromatographic separations were carried out following protocols defined by Still et al. ${ }^{19}$ with silica gel 60 (40-63 $\mu \mathrm{m})$ as the stationary phase and using the AR- or HPLC-grade solvents indicated. The melting points of solids purified by such means were recorded directly (i.e., after they had crystallized from the concentrated chromatographic fractions). Starting materials and reagents were generally available from the SigmaAldrich, Merck, TCI, Strem, or Lancaster Chemical Companies and were used as supplied. Drying agents and other inorganic salts were purchased from the AJAX, BDH, or Unilab Chemical
Companies. Tetrahydrofuran (THF), methanol, and dichloromethane were dried using a Glass Contour solvent purification system that is based upon a technology originally described by Grubbs et al. ${ }^{20}$ Where necessary, reactions were performed under a nitrogen atmosphere.

Specific Chemical Transformations. (E)-2-Methoxy-1(methoxymethoxy)-4-(3-(methoxymethoxy)prop-1-en-1-yl)benzene (4). Step i: Using a procedure analogous to that described by Bazin et al., ${ }^{21}$ a magnetically stirred solution of ferulic acid (3) (30.2 g, $155.5 \mathrm{mmol}$ ) in dry methanol (200 $\mathrm{mL}$ ) was treated with five drops of concentrated sulfuric acid, and the resulting mixture was heated under reflux for $24 \mathrm{~h}$. The solution was then cooled to room temperature, and the solvent was removed under reduced pressure. The residue thus obtained was dissolved in dichloromethane, and the resulting solution was washed with $\mathrm{NaHCO}_{3}(2 \times 100 \mathrm{~mL}$ of a saturated aqueous solution) before being dried $\left(\mathrm{MgSO}_{4}\right)$, filtered, and concentrated under reduced pressure to afford a pale-yellow oil. Subjection of this oil to flash chromatography [silica, petroleum ether $\rightarrow 1: 5 \mathrm{v} / \mathrm{v}$ ethyl acetate/petroleum ether gradient elution] and concentration of the relevant fractions $\left(R_{\mathrm{f}}=0.6\right.$ in $1: 1 \mathrm{v} / \mathrm{v}$ ethyl acetate/petroleum ether) under reduced pressure afforded ferulic acid methyl ester ${ }^{22}(30.0 \mathrm{~g}, 93 \%)$ as a white, crystalline solid, $\mathrm{mp}=60.9-62.1^{\circ} \mathrm{C}\left(\right.$ lit. $\left.{ }^{22} \mathrm{mp}=65^{\circ} \mathrm{C}\right)$. ${ }^{1} \mathrm{H}$ NMR (300 MHz, $\left.\mathrm{CDCl}_{3}\right) \delta 7.62(\mathrm{~d}, J=15.9 \mathrm{~Hz}, 1 \mathrm{H}), 7.07$ $(\mathrm{dd}, J=8.2$ and $1.9 \mathrm{~Hz}, 1 \mathrm{H}), 7.02(\mathrm{~d}, J=1.9 \mathrm{~Hz}, 1 \mathrm{H}), 6.92(\mathrm{~d}, J$ $=8.2 \mathrm{~Hz}, 1 \mathrm{H}), 6.29(\mathrm{~d}, J=15.9 \mathrm{~Hz}, 1 \mathrm{H}), 5.90(\mathrm{~m}, 1 \mathrm{H}), 3.92(\mathrm{~s}$, $3 \mathrm{H}), 3.79$ (s, $3 \mathrm{H}) ;{ }^{13} \mathrm{C}$ NMR $\left(100 \mathrm{MHz}, \mathrm{CDCl}_{3}\right) \delta 167.8$, 148.1, 146.9, 145.1, 127.1, 123.2, 115.3, 114.9, 109.5, 56.1, 51.7. These spectral data matched those reported by $\mathrm{Li}$ et al. ${ }^{22}$

Step ii: Chloromethyl methyl ether (MOM-Cl) $(12.0 \mathrm{~mL}$, $158.3 \mathrm{mmol}$ ) was added dropwise to a magnetically stirred solution of ferulic acid methyl ester $(22.0 \mathrm{~g}, 105.6 \mathrm{mmol})$ and Hünig's base $\left(i-\mathrm{Pr}_{2} \mathrm{NEt}\right)(27.6 \mathrm{~mL}, 158.3 \mathrm{mmol})$ in dry dichloromethane $(100 \mathrm{~mL})$ maintained at $0{ }^{\circ} \mathrm{C}$. The resulting mixture was allowed to warm to $22{ }^{\circ} \mathrm{C}$ and stirred at this temperature for $14 \mathrm{~h}$ whilst being maintained under nitrogen then quenched with $\mathrm{NH}_{4} \mathrm{Cl}(50 \mathrm{~mL}$ of a saturated aqueous solution). The mixture thus obtained was stirred at $22{ }^{\circ} \mathrm{C}$ for a further $1 \mathrm{~h}$ then treated with $\mathrm{NaHCO}_{3}(100 \mathrm{~mL}$ of a saturated aqueous solution). The separated aqueous layer was extracted with ethyl acetate $(3 \times 100 \mathrm{~mL})$ and the combined organic phases were washed with $\mathrm{Na}_{2} \mathrm{CO}_{3}(3 \times 50 \mathrm{~mL}$ of a saturated aqueous solution) and brine $(3 \times 50 \mathrm{~mL})$ before being dried $\left(\mathrm{MgSO}_{4}\right)$, filtered, and concentrated under reduced pressure to afford a yellow oil. This oil was subjected to flash chromatography [silica, dichloromethane $\rightarrow 1: 20 \mathrm{v} / \mathrm{v} \mathrm{Et}_{2} \mathrm{O} /$ dichloromethane gradient elution], and concentration of the relevant fractions $\left(R_{\mathrm{f}}=0.8\right.$ in $1: 9 \mathrm{v} / \mathrm{v} \mathrm{Et}_{2} \mathrm{O} /$ dichloromethane) under reduced pressure afforded methyl (E)-3-(3-methoxy-4(methoxymethoxy)phenyl)acrylate ${ }^{23}(25.0 \mathrm{~g}, 94 \%)$ as a clear, light-yellow oil. ${ }^{1} \mathrm{H}$ NMR $\left(400 \mathrm{MHz}, \mathrm{CDCl}_{3}\right) \delta 7.63(\mathrm{~d}, J=$ $16.0 \mathrm{~Hz}, 1 \mathrm{H}), 7.15(\mathrm{~d}, J=8.1 \mathrm{~Hz}, 1 \mathrm{H}), 7.07(\mathrm{~m}, 2 \mathrm{H}), 6.33(\mathrm{~d}, J$ $=16.0 \mathrm{~Hz}, 1 \mathrm{H}), 5.26(\mathrm{~s}, 2 \mathrm{H}), 3.91(\mathrm{~s}, 3 \mathrm{H}), 3.80(\mathrm{~s}, 3 \mathrm{H}), 3.51$ $(\mathrm{s}, 3 \mathrm{H}) ;{ }^{13} \mathrm{C} \mathrm{NMR}\left(100 \mathrm{MHz}, \mathrm{CDCl}_{3}\right) \delta 167.7,149.9,148.6$, $144.8,128.8,122.4,116.2,115.9,110.4,95.3,56.5,56.1,51.8$. These spectral data matched those reported by Lui et al. ${ }^{23}$

Step iii: Aluminum trichloride (14.45 g, $109.2 \mathrm{mmol}$ ) was added to dry THF $(160 \mathrm{~mL})$, and the resulting suspension was stirred at $0{ }^{\circ} \mathrm{C}$ under nitrogen for $0.25 \mathrm{~h} . \mathrm{LiAlH}_{4}(150 \mathrm{~mL}$ of a $1 \mathrm{M}$ solution in THF, $150 \mathrm{mmol}$ ) was then added dropwise over $0.5 \mathrm{~h}$, and the resulting suspension was stirred for a further $0.5 \mathrm{~h}$ at $0{ }^{\circ} \mathrm{C}$. A solution of methyl (E)-3-(3-methoxy-4- 
(methoxymethoxy)phenyl)acrylate $(24.97 \mathrm{~g}, 99.0 \mathrm{mmol})$ in dry THF $(20 \mathrm{~mL}$ ) was then added (dropwise over $0.5 \mathrm{~h}$ ) to the reaction mixture that was then stirred at $0{ }^{\circ} \mathrm{C}$ for $0.5 \mathrm{~h}$ before being allowed to warm to $22{ }^{\circ} \mathrm{C}$ and stirred for an additional 1 $\mathrm{h}$ at this temperature. The reaction mixture was then cooled to $0{ }^{\circ} \mathrm{C}$, water $(5.7 \mathrm{~mL})$ was added dropwise (Caution: hydrogen gas evolution), and stirring then continued for $0.25 \mathrm{~h}$. After this time, $\mathrm{NaOH}(5.7 \mathrm{~mL}$ of a $15 \% \mathrm{w} / \mathrm{v}$ aqueous solution) was added to the reaction mixture, and stirring continued for an additional $0.25 \mathrm{~h}$ before more water $(17.1 \mathrm{~mL})$ was added. The resulting mixture was warmed to $22{ }^{\circ} \mathrm{C}$, diluted with $\mathrm{Et}_{2} \mathrm{O}(10$ $\mathrm{mL})$, then dried $\left(\mathrm{MgSO}_{4}\right)$, filtered, and concentrated under reduced pressure to afford a light-yellow oil. Subjection of this material to flash chromatography (silica, petroleum ether $\rightarrow$ ethyl acetate gradient elution) and concentration of the relevant fractions $\left(R_{\mathrm{f}}=0.4\right.$ in $1: 1 \mathrm{v} / \mathrm{v}$ ethyl acetate/petroleum ether) under reduced pressure afforded (E)-3-(3-methoxy-4(methoxymethoxy)phenyl)prop-2-en-1-ol ${ }^{24}(21.21 \mathrm{~g}, 96 \%)$ as a white, crystalline solid, $\mathrm{mp}=51.2-52.5{ }^{\circ} \mathrm{C}$. ${ }^{1} \mathrm{H}$ NMR $(400$ $\left.\mathrm{MHz}_{\mathrm{CDCl}}\right) \delta 7.09(\mathrm{~d}, J=8.3 \mathrm{~Hz}, 1 \mathrm{H}), 6.95(\mathrm{~d}, J=2.0 \mathrm{~Hz}$, $1 \mathrm{H}), 6.90(\mathrm{dd}, J=8.3$ and $2.0 \mathrm{~Hz}, 1 \mathrm{H}), 6.55(\mathrm{~d}, J=15.9 \mathrm{~Hz}$, $1 \mathrm{H}), 6.26(\mathrm{dt}, J=15.9$ and $5.9 \mathrm{~Hz}, 1 \mathrm{H}), 5.23(\mathrm{~s}, 2 \mathrm{H}), 4.31(\mathrm{dd}$, $J=5.9$ and $1.5 \mathrm{~Hz}, 2 \mathrm{H}), 3.89(\mathrm{~s}, 3 \mathrm{H}), 3.51(\mathrm{~s}, 3 \mathrm{H})$ (signal due to hydroxyl group proton not observed); ${ }^{13} \mathrm{C}$ NMR (100 MHz, $\left.\mathrm{CDCl}_{3}\right) \delta 149.8,146.4,131.4,131.1,127.2,119.7,116.3,109.5$, 95.5, 63.9, 56.4, 56.0; IR $\nu_{\max } 3399,2935,1512,1464,1417$, 1263, 1154, 1132, 1077, 993, $969 \mathrm{~cm}^{-1}$; MS (ESI, +ve) $\mathrm{m} / z$ $247(100)[\mathrm{M}+\mathrm{Na}]^{+}$; HRMS calcd for $\mathrm{C}_{12} \mathrm{H}_{16} \mathrm{NaO}_{4}[\mathrm{M}+$ $\mathrm{Na}]^{+}:$247.0946, found: 219.0946 .

Step iv: MOM-Cl (10.7 mL, $141.3 \mathrm{mmol})$ was added dropwise to a magnetically stirred solution of (E)-3-(3methoxy-4-(methoxymethoxy)phenyl)prop-2-en-1-ol (21.18 g, $94.2 \mathrm{mmol})$ and Hünig's base $(24.6 \mathrm{~mL}, 141.3 \mathrm{mmol})$ in dry dichloromethane $(94 \mathrm{~mL})$ maintained at $0{ }^{\circ} \mathrm{C}$ under a nitrogen atmosphere. The resulting mixture was allowed to warm to 22 ${ }^{\circ} \mathrm{C}$ and stirred at this temperature for $14 \mathrm{~h}$ before being quenched with $\mathrm{NaHCO}_{3}$ (50 mL of a saturated aqueous solution). The mixture thus obtained was stirred for a further 1 $h$, then the organic layer was separated and washed with $\mathrm{NaHCO}_{3}(1 \times 50 \mathrm{~mL}$ of a saturated aqueous solution $)$. The combined aqueous layers were extracted with ethyl acetate $(3 \times$ $100 \mathrm{~mL}$ ), and then the combined organic phases were washed with $\mathrm{NH}_{4} \mathrm{Cl}(3 \times 50 \mathrm{~mL}$ of a saturated aqueous solution $)$, water $(1 \times 50 \mathrm{~mL})$, and brine $(3 \times 50 \mathrm{~mL})$ before being dried $\left(\mathrm{MgSO}_{4}\right)$, filtered, and concentrated under reduced pressure to afford a light-yellow oil. This oil was subjected to flash chromatography (silica, dichloromethane $\rightarrow 1: 20 \mathrm{v} / \mathrm{v} \mathrm{Et}_{2} \mathrm{O} /$ dichloromethane gradient elution), and concentration of the relevant fractions $\left(R_{\mathrm{f}}=0.7\right.$ in $1: 20 \mathrm{v} / \mathrm{v} \mathrm{Et}_{2} \mathrm{O} /$ dichloromethane) under reduced pressure afforded compound $4(25.0 \mathrm{~g}, 94 \%)$ as a clear, colorless oil. ${ }^{1} \mathrm{H}$ NMR $\left(300 \mathrm{MHz}, \mathrm{CDCl}_{3}\right) \delta 7.09(\mathrm{~d}, J=$ $8.2 \mathrm{~Hz}, 1 \mathrm{H}), 6.96(\mathrm{~d}, J=1.8 \mathrm{~Hz}, 1 \mathrm{H}), 6.91(\mathrm{dd}, J=8.2$ and 1.8 $\mathrm{Hz}, 1 \mathrm{H}), 6.57(\mathrm{~d}, J=15.9 \mathrm{~Hz}, 1 \mathrm{H}), 6.18(\mathrm{dt}, J=15.9$ and 6.2 $\mathrm{Hz}, 1 \mathrm{H}), 5.23(\mathrm{~s}, 2 \mathrm{H}), 4.70(\mathrm{~s}, 2 \mathrm{H}), 4.22(\mathrm{~d}, J=6.2 \mathrm{~Hz}, 1 \mathrm{H})$, $3.89(\mathrm{~s}, 3 \mathrm{H}), 3.51(\mathrm{~s}, 3 \mathrm{H}), 3.41(\mathrm{~s}, 3 \mathrm{H}) ;{ }^{13} \mathrm{C}$ NMR (100 MHz, $\left.\mathrm{CDCl}_{3}\right) \delta 149.8,146.4,132.6,131.4,124.2,119.8,116.3,109.5$, 95.7, 95.5, 68.0, 56.4, 56.0, 55.5; IR $\nu_{\max } 3375,2934,1512$, 1464, 1265, 1152, 1133, 1102, 1078, 1036, 995, $920 \mathrm{~cm}^{-1}$; MS (ESI, +ve) $m / z 291(100)[\mathrm{M}+\mathrm{Na}]^{+}, 160$ (85); HRMS calcd for $\mathrm{C}_{14} \mathrm{H}_{20} \mathrm{NaO}_{5}[\mathrm{M}+\mathrm{Na}]^{+}: 219.1208$, found: 219.1208 .

$(1 R, 2 R)-1-(3-M e t h o x y-4-(m e t h o x y m e t h o x y) p h e n y l)-3-$ (methoxymethoxy)propane-1,2-diol (5). $\mathrm{MeSO}_{2} \mathrm{NH}_{2}$ (856 $\mathrm{mg}, 9.0 \mathrm{mmol}$ ) was added to a magnetically stirred solution of $\mathrm{AD}$-mix- $\alpha(12.48 \mathrm{~g})$ in $t$-butanol/water $(120 \mathrm{~mL}$ of a $1: 1 \mathrm{v} / \mathrm{v}$ mixture) maintained at $22{ }^{\circ} \mathrm{C}$, and the resulting suspension was stirred for $0.5 \mathrm{~h}$ after which time both phases had become clear. This mixture was then cooled to $0{ }^{\circ} \mathrm{C}$ before being treated with a solution of alkene $4(2.00 \mathrm{~g}, 7.8 \mathrm{mmol})$ in $t$-butanol $(2 \mathrm{~mL})$. The reaction mixture thus obtained was stirred vigorously at 0 ${ }^{\circ} \mathrm{C}$ for $72 \mathrm{~h}$, quenched with $\mathrm{Na}_{2} \mathrm{SO}_{3}(1.0 \mathrm{~g})$, then allowed to warm to $22{ }^{\circ} \mathrm{C}$ and stirred at this temperature $12 \mathrm{~h}$. The resulting solution was concentrated under reduced pressure, and the residue thus obtained subjected to flash chromatography [silica, 1:1 v/v ethyl acetate/petroleum ether $\rightarrow$ ethyl acetate gradient elution]. Concentration of the relevant fractions $\left(R_{\mathrm{f}}=0.4\right.$ in ethyl acetate) under reduced pressure afforded compound $5(1.85 \mathrm{~g}, 78 \%)$ as a clear, colorless gum, $[\alpha]^{25}=+10.7\left(c=1.02, \mathrm{CHCl}_{3}\right) .{ }^{1} \mathrm{H}$ NMR $(400 \mathrm{MHz}$, $\left.\mathrm{CDCl}_{3}\right) \delta 7.12(\mathrm{~d}, J=8.2 \mathrm{~Hz}, 1 \mathrm{H}), 6.98(\mathrm{~d}, J=1.9 \mathrm{~Hz}, 1 \mathrm{H})$, $6.87(\mathrm{dd}, J=8.2$ and $1.9 \mathrm{~Hz}, 1 \mathrm{H}), 5.22(\mathrm{~s}, 2 \mathrm{H}), 4.64(\mathrm{~m}, 3 \mathrm{H})$, $3.89(\mathrm{~s}, 3 \mathrm{H}), 3.80(\mathrm{~m}, 1 \mathrm{H}), 3.57(\mathrm{dd}, J=10.7$ and $3.3 \mathrm{~Hz}, 1 \mathrm{H})$, $3.52(\mathrm{dd}, J=10.7$ and $5.5 \mathrm{~Hz}, 1 \mathrm{H}), 3.51(\mathrm{~s}, 3 \mathrm{H}), 3.39(\mathrm{~s}, 3 \mathrm{H})$, 3.08 (broad d, $J=5.4 \mathrm{~Hz}, 1 \mathrm{H}), 3.00($ br d, $J=1.7 \mathrm{~Hz}, 1 \mathrm{H}) ;{ }^{13} \mathrm{C}$ NMR $\left(100 \mathrm{MHz}, \mathrm{CDCl}_{3}\right) \delta 150.0,146.4,134.8,119.4,116.4$, $110.3,97.5,95.6,75.0,74.7,70.1,56.4,56.1,55.8$; IR $\nu_{\max } 3435$, 2937, 1594, 1513, 1265, 1153, 1034, 989, $920 \mathrm{~cm}^{-1}$; MS (ESI, +ve) $m / z 325(100)[\mathrm{M}+\mathrm{Na}]^{+}$; HRMS calcd for $\mathrm{C}_{14} \mathrm{H}_{22} \mathrm{NaO}_{7}$ $[\mathrm{M}+\mathrm{Na}]^{+}:$325.1263, found: 325.1259 .

(R)-2-Hydroxy-1-(3-methoxy-4-(methoxymethoxy)phenyl)-3-(methoxymethoxy)propan-1-one (6). DDQ (2.78 $\mathrm{g}, 12.25 \mathrm{mmol}$ ) was added to a magnetically stirred solution of diol 5 (1.79 g, $5.92 \mathrm{mmol})$ in dry benzene $(30 \mathrm{~mL})$ maintained under nitrogen at $22{ }^{\circ} \mathrm{C}$. The resulting suspension was sonicated for $5 \mathrm{~h}$ during which time the temperature of the water in the sonication bath was maintained between 22 and 30 ${ }^{\circ} \mathrm{C}$ through the addition of ice. The reaction mixture thus obtained was cooled then filtered, and the filtrate was concentrated reduced pressure. The residue thus obtained was triturated with cold dichloromethane $(4 \times 10 \mathrm{~mL})$, and the combined washings were filtered and the filtrate again concentrated under reduced pressure to afford a black oil. Subjection of this material to flash chromatography [silica, dichloromethane $\rightarrow 3: 7 \mathrm{v} / \mathrm{v} \mathrm{Et}_{2} \mathrm{O} /$ dichloromethane gradient elution] and concentration of the relevant fractions $\left(R_{\mathrm{f}}=0.5\right.$ in 3:7 $\mathrm{v} / \mathrm{v} \quad \mathrm{Et}_{2} \mathrm{O} /$ dichloromethane) under reduced pressure afforded compound $6(1.53 \mathrm{~g}, 86 \%)$ as a clear, pale-yellow oil, $[\alpha]_{\mathrm{D}}^{25}=-20.0\left(c=1.0, \mathrm{CHCl}_{3}\right) .{ }^{1} \mathrm{H}$ NMR $(400 \mathrm{MHz}$, $\left.\mathrm{CDCl}_{3}\right) \delta 7.53(\mathrm{~d}, J=2.0 \mathrm{~Hz}, 1 \mathrm{H}), 7.51(\mathrm{dd}, J=8.4$ and $2.0 \mathrm{~Hz}$, $1 \mathrm{H}), 7.21(\mathrm{~d}, J=8.4 \mathrm{~Hz}, 1 \mathrm{H}), 5.32(\mathrm{~s}, 2 \mathrm{H}), 5.19$ (dddsimplifies to a dd upon addition of $\mathrm{D}_{2} \mathrm{O}, J=7.4,4.5$, and 3.1 $\mathrm{Hz}, 1 \mathrm{H}), 4.60(\mathrm{~d}, J=6.6 \mathrm{~Hz}, 1 \mathrm{H}), 4.56(\mathrm{~d}, J=6.6 \mathrm{~Hz}, 1 \mathrm{H})$, $3.99\left(\mathrm{~d}\right.$-disappears upon addition of $\left.\mathrm{D}_{2} \mathrm{O}, J=6.8 \mathrm{~Hz}, 1 \mathrm{H}\right)$, $3.95(\mathrm{~s}, 3 \mathrm{H}), 3.92(\mathrm{dd}, J=10.8$ and $3.1 \mathrm{~Hz}, 1 \mathrm{H}), 3.85(\mathrm{dd}, J=$ 10.8 and $4.5 \mathrm{~Hz}, 1 \mathrm{H}), 3.52(\mathrm{~s}, 3 \mathrm{H}), 3.22(\mathrm{~s}, 3 \mathrm{H}) ;{ }^{13} \mathrm{C}$ NMR $\left(100 \mathrm{MHz}, \mathrm{CDCl}_{3}\right) \delta 197.8,151.8,150.0,128.0,123.1,114.7$, $111.4,96.9,95.2,73.2,71.1,56.7,56.3,55.5$; IR $\nu_{\max } 3444$, 2937, 1676, 1595, 1512, 1464, 1266, 1148, 1115, 1080, 1032, 980, $920 \mathrm{~cm}^{-1}$; MS (ESI, +ve) $\mathrm{m} / z 323(100)[\mathrm{M}+\mathrm{Na}]^{+}$; HRMS calcd for $\mathrm{C}_{14} \mathrm{H}_{20} \mathrm{NaO}_{7}[\mathrm{M}+\mathrm{Na}]^{+}$: 323.1107, found: 323.1107.

(R)-1-(3-Methoxy-4-(methoxymethoxy)phenyl)-3-(methoxymethoxy)-1-oxopropan-2-yl 4-Methylbenzenesulfonate (7). A magnetically stirred solution of alcohol 6 (1.52 g $5.06 \mathrm{mmol})$ in dry dichloromethane $(20 \mathrm{~mL})$ maintained under nitrogen was cooled to $0{ }^{\circ} \mathrm{C}$ then treated with pyridine $(600$ $\mu \mathrm{L}, 7.59 \mathrm{mmol})$ and $p$-toluenesulfonic acid anhydride $(2.48 \mathrm{~g}$, 
$7.6 \mathrm{mmol}$ ). The ensuing mixture was allowed to stir at $0{ }^{\circ} \mathrm{C}$ for $0.5 \mathrm{~h}$ then warmed to $22{ }^{\circ} \mathrm{C}$ and stirred at this temperature for an additional $1 \mathrm{~h}$ before being re-cooled to $0{ }^{\circ} \mathrm{C}$, quenched with $\mathrm{pH} 7$ buffer ( $2 \mathrm{~mL}$ of a $1 \mathrm{M}$ aqueous solution), then allowed to warm to $22{ }^{\circ} \mathrm{C}$. The mixture thus obtained was diluted with ethyl acetate $(50 \mathrm{~mL})$ before being washed with $\mathrm{NH}_{4} \mathrm{Cl}(1 \times$ $40 \mathrm{~mL})$ and brine $(1 \times 10 \mathrm{~mL})$ The separated aqueous phase was extracted with ethyl acetate $(3 \times 20 \mathrm{~mL})$, and the combined organic phases were washed with brine $(3 \times 20 \mathrm{~mL})$ before being dried $\left(\mathrm{MgSO}_{4}\right)$, filtered, then concentrated under reduced pressure to afford an orange oil. This oil was subjected to flash chromatography (silica, dichloromethane $\rightarrow 1: 9 \mathrm{v} / \mathrm{v}$ $\mathrm{Et}_{2} \mathrm{O} /$ dichloromethane gradient elution) and concentration of the relevant fractions $\left(R_{\mathrm{f}}=0.6\right.$ in $1: 9 \mathrm{v} / \mathrm{v} \mathrm{Et}_{2} \mathrm{O} /$ dichloromethane) under reduced pressure afforded ester $7(2.14 \mathrm{~g}$, $93 \%)$ as a white, crystalline solid, $\mathrm{mp}=93.5-95.8^{\circ} \mathrm{C},[\alpha]^{25} \mathrm{D}=$ $-34\left(c=1.0, \mathrm{CHCl}_{3}\right) .{ }^{1} \mathrm{H} \mathrm{NMR}\left(400 \mathrm{MHz}, \mathrm{CDCl}_{3}\right) \delta 7.75(\mathrm{~d}$, $J=8.2 \mathrm{~Hz}, 2 \mathrm{H}), 7.53(\mathrm{dd}, J=8.5$ and $1.8 \mathrm{~Hz}, 1 \mathrm{H}), 7.46(\mathrm{~d}, J=$ $1.8 \mathrm{~Hz}, 1 \mathrm{H}), 7.26(\mathrm{~d}, J=8.2 \mathrm{~Hz}, 2 \mathrm{H}), 7.17(\mathrm{~d}, J=8.5 \mathrm{~Hz}, 1 \mathrm{H})$, $5.82(\mathrm{t}, J=4.9 \mathrm{~Hz}, 1 \mathrm{H}), 5.32(\mathrm{~s}, 2 \mathrm{H}), 4.54(\mathrm{~m}, 2 \mathrm{H}), 3.93(\mathrm{~d}, J=$ $4.9 \mathrm{~Hz}, 2 \mathrm{H}), 3.91(\mathrm{~s}, 3 \mathrm{H}), 3.52(\mathrm{~s}, 3 \mathrm{H}), 3.25$ (s, 3H), $2.41(\mathrm{~s}$, $3 \mathrm{H}) ;{ }^{13} \mathrm{C} \mathrm{NMR}\left(100 \mathrm{MHz}, \mathrm{CDCl}_{3}\right) \delta 191.6,151.7,149.8$, $145.2,133.5,129.8,128.7,128.2,123.5,114.6,111.6,96.7,95.2$, 79.8, 67.4, 56.7, 56.2, 55.6, 21.8; IR $\nu_{\max } 3374,2940,1690$, 1595, 1512, 1464, 1421, 1364, 1267, 1176, 1079, 1030, 976, 923, 814, $666 \mathrm{~cm}^{-1}$; MS (ESI, +ve) $\mathrm{m} / z 477(100)[\mathrm{M}+\mathrm{Na}]^{+}$; HRMS calcd for $\mathrm{C}_{21} \mathrm{H}_{26} \mathrm{NaO}_{9} \mathrm{~S}[\mathrm{M}+\mathrm{Na}]^{+}: 477.1195$, found: 477.1194.

(E)-3-(3-Methoxy-4-((1-(3-methoxy-4-(methoxymethoxy)phenyl)-3-(methoxymethoxy)-1-oxopropan-2-yl)oxy)phenyl)acrylaldehyde (9). Cesium carbonate (1.09 g, 3.34 mmol) was added to a solution of 18 -crown-6 (874 mg, 3.31 mmol) and coniferaldehyde (8) $(590 \mathrm{mg}, 3.31 \mathrm{mmol})$ in dry acetonitrile $(9 \mathrm{~mL})$ maintained under nitrogen at $22{ }^{\circ} \mathrm{C}$. The resulting suspension was sonicated for $0.5 \mathrm{~h}$, then the supernatant liquid was taken up in a syringe and added dropwise, over $0.25 \mathrm{~h}$, to a magnetically solution of tosylate 7 (990 mg, $2.17 \mathrm{mmol})$ in dry acetonitrile $(20 \mathrm{~mL})$ maintained under nitrogen at $0{ }^{\circ} \mathrm{C}$. The resulting solution was stirred at 0 ${ }^{\circ} \mathrm{C}$ for $5 \mathrm{~h}$ then quenched with $\mathrm{pH} 7$ buffer $(2 \mathrm{~mL}$ of a $1 \mathrm{M}$ aqueous solution) before being allowed to warm to $22{ }^{\circ} \mathrm{C}$. The ensuing mixture was diluted with ethyl acetate $(20 \mathrm{~mL})$, and the separated aqueous phase was extracted with ethyl acetate (3 $\times 20 \mathrm{~mL}$ ). The combined organic phases were washed with brine $(3 \times 20 \mathrm{~mL})$ then dried $\left(\mathrm{MgSO}_{4}\right)$, filtered, and concentrated under reduced pressure. The resulting lightyellow oil was subjected to flash chromatography [silica, dichloromethane $\rightarrow 3: 7 \mathrm{v} / \mathrm{v} \mathrm{Et}_{2} \mathrm{O} /$ dichloromethane gradient elution], and concentration of the relevant fractions $\left(R_{\mathrm{f}}=0.2 \mathrm{in}\right.$ 1:9 $\mathrm{v} / \mathrm{v} \mathrm{Et}_{2} \mathrm{O} /$ dichloromethane) under reduced pressure afforded aryl ether $9(470 \mathrm{mg}, 47 \%)$ as a clear, pale-yellow oil, $[\alpha]_{\mathrm{D}}^{25}=0\left(c=2.0, \mathrm{CHCl}_{3}\right) .{ }^{1} \mathrm{H}$ NMR $\left(400 \mathrm{MHz}, \mathrm{CDCl}_{3}\right)$ $\delta 9.63(\mathrm{~d}, J=7.7 \mathrm{~Hz}, 1 \mathrm{H}), 7.74(\mathrm{dd}, J=8.5$ and $1.1 \mathrm{~Hz}, 1 \mathrm{H})$, $7.66(\mathrm{~s}, 1 \mathrm{H}), 7.35(\mathrm{~d}, J=15.8 \mathrm{~Hz}, 1 \mathrm{H}), 7.18(\mathrm{~d}, J=8.5 \mathrm{~Hz}$, $1 \mathrm{H}), 7.05(\mathrm{~s}, 1 \mathrm{H}), 7.02(\mathrm{~d}, J=8.3 \mathrm{~Hz}, 1 \mathrm{H}), 6.81(\mathrm{~d}, J=8.3 \mathrm{~Hz}$, $1 \mathrm{H}), 6.56(\mathrm{dd}, J=15.8$ and $7.7 \mathrm{~Hz}, 1 \mathrm{H}), 5.62(\mathrm{~m}, 1 \mathrm{H}), 5.30(\mathrm{~s}$, $2 \mathrm{H}), 4.69$ (s, 2H), 4.19-4.07 (complex m, 2H), 3.91 (s, 3H), $3.84(\mathrm{~s}, 3 \mathrm{H}), 3.50(\mathrm{~s}, 3 \mathrm{H}), 3.32(\mathrm{~s}, 3 \mathrm{H}) ;{ }^{13} \mathrm{C}$ NMR (100 MHz, $\left.\mathrm{CDCl}_{3}\right) \delta 194.5,193.6,152.6,151.6,150.2,150.0,149.8,129.0$, 128.5, 127.3, 123.4, 123.1, 115.5, 114.6, 111.7, 111.2, 96.9, 95.1, 81.7, 68.1, 56.7, 56.1(1), 56.0(7), 55.6; IR $\nu_{\max } 3369,2932$, $1671,1595,1509,1268,1141,1127,1079,1032,975,804$ $\mathrm{cm}^{-1}$; MS (ESI, +ve) $\mathrm{m} / z 484(100)[\mathrm{M}+\mathrm{Na}]^{+}$; HRMS calcd for $\mathrm{C}_{24} \mathrm{H}_{28} \mathrm{NaO}_{9}[\mathrm{M}+\mathrm{Na}]^{+}$: 483.1631, found: 483.1632 .

(E)-3-(4-((3-Hydroxy-1-(4-hydroxy-3-methoxyphenyl)-1oxopropan-2-yl)oxy)-3-met-hoxyphenyl)acrylaldehyde (10). A magnetically stirred solution of aryl ether 9 (465 mg, 1.02 $\mathrm{mmol})$ in dry isopropanol $(30 \mathrm{~mL})$ was treated with concentrated hydrochloric acid (3 drops), and the resulting solution was heated at $60{ }^{\circ} \mathrm{C}$ for $22 \mathrm{~h}$. The cooled reaction mixture was quenched with $\mathrm{NaHCO}_{3}(20 \mathrm{~mL}$ of a saturated solution) then diluted with ethyl acetate $(60 \mathrm{~mL})$ before being washed with $\mathrm{NaHCO}_{3}(2 \times 20 \mathrm{~mL})$. The separated aqueous phases were extracted with ethyl acetate $(3 \times 20 \mathrm{~mL})$, and the combined organic phases were washed with brine $(3 \times 20 \mathrm{~mL})$ then dried $\left(\mathrm{MgSO}_{4}\right)$, filtered, and concentrated under reduced pressure to afford a pale-yellow oil. This oil was subjected to flash chromatography (silica, 1:1 v/v ethyl acetate/petroleum ether $\rightarrow$ ethyl acetate gradient elution), and concentration of the relevant fractions $\left(R_{\mathrm{f}}=0.2\right.$ in $3: 1 \mathrm{v} / \mathrm{v}$ ethyl acetate /petroleum ether) under reduced pressure afforded alcohol 10 (291 $\mathrm{mg}, 76 \%)$ as a pale-yellow foam, $[\alpha]^{25}=0(c=0.5$, $\mathrm{CHCl}_{3}$ ). ${ }^{1} \mathrm{H}$ NMR $\left(400 \mathrm{MHz}, \mathrm{CDCl}_{3}\right) \delta 9.65(\mathrm{~d}, J=7.7 \mathrm{~Hz}$, $1 \mathrm{H}), 7.70(\mathrm{dd}, J=8.4$ and $1.9 \mathrm{~Hz}, 1 \mathrm{H}), 7.61(\mathrm{~d}, J=1.9 \mathrm{~Hz}$, $1 \mathrm{H}), 7.37$ (d, $J=15.9 \mathrm{~Hz}, 1 \mathrm{H}), 7.08(\mathrm{~d}, J=1.9 \mathrm{~Hz}, 1 \mathrm{H}), 7.04$ $(\mathrm{dd}, J=8.3$ and $2.0 \mathrm{~Hz}, 1 \mathrm{H}), 6.96(\mathrm{~d}, J=8.3 \mathrm{~Hz}, 1 \mathrm{H}), 6.83(\mathrm{~d}, J$ $=8.3 \mathrm{~Hz}, 1 \mathrm{H}), 6.55(\mathrm{dd}, J=15.9$ and $7.7 \mathrm{~Hz}, 1 \mathrm{H}), 6.17$ (broad s, $1 \mathrm{H}), 5.55(\mathrm{~m}, 1 \mathrm{H}), 4.13(\mathrm{~m}, 2 \mathrm{H}), 3.94(\mathrm{~s}, 3 \mathrm{H}), 3.90(\mathrm{~s}, 3 \mathrm{H})$, 2.79 (broad t, $J=6.3 \mathrm{~Hz}, 1 \mathrm{H}) ;{ }^{13} \mathrm{C} \mathrm{NMR}\left(100 \mathrm{MHz}, \mathrm{CDCl}_{3}\right) \delta$ 194.0, 193.6, 152.4, 151.5, 150.5, 149.7, 147.1, 129.1, 127.6(2), 127.5(7), 124.2, 123.1, 116.7, 114.3, 111.2, 110.7, 83.4, 63.9, 56.3, 56.1; IR $\nu_{\max } 3356,2938,1668,1620,1591,1509,1426$, $1270,1137,1030,734 \mathrm{~cm}^{-1}$; MS (ESI, +ve) $\mathrm{m} / z 395$ (100) [M $+\mathrm{Na}]^{+}$; HRMS calcd for $\mathrm{C}_{20} \mathrm{H}_{20} \mathrm{NaO}_{7}[\mathrm{M}+\mathrm{Na}]^{+}$: 395.1107, found: 395.1110 .

Compounds ( \pm )-1 and ( \pm )-2. Polymer-supported borohydride $\left(2.5 \mathrm{mmol} \mathrm{g}^{-1}\right.$ on Amberlite A-26, $400 \mathrm{mg}, 1.0 \mathrm{mmol}$ ) was added in one portion to a magnetically stirred solution of compound $10(77 \mathrm{mg}, 0.21 \mathrm{mmol})$ in methanol $(5 \mathrm{~mL})$ maintained under nitrogen at $0{ }^{\circ} \mathrm{C}$. The ensuing mixture was stirred at this temperature for $4 \mathrm{~h}$ then allowed to warm to 22 ${ }^{\circ} \mathrm{C}$ before being filtered, and the solids thus retained were washed with acetic acid in methanol $(3 \times 10 \mathrm{~mL}$ of a $1: 99 \mathrm{v} / \mathrm{v}$ mixture). The combined filtrates were concentrated under reduced pressure to give a ca. 7:1 mixture of the title compounds (68 mg, 87\%) as a light-yellow oil. Subjection of this material to preparative, reverse phase HPLC (Gemini C18 $5 \mu 150 \times 21.20 \mathrm{~mm}^{2}$ column, 25:74.95:0.05 v/v/v/v methanol/ water/acetic acid elution, flow rate $17.0 \mathrm{~mL} / \mathrm{min}$ ) afforded two fractions, $\mathrm{A}$ and $\mathrm{B}$.

Concentration of fraction $\mathrm{A}\left(t_{\mathrm{R}}=12.0 \mathrm{~min}\right)$ afforded compound $( \pm)-2^{4 \mathrm{e}, 10}(9 \mathrm{mg}, 12 \%)$ as a white powder. ${ }^{1} \mathrm{H}$ NMR [300 MHz, $\left.\left(\mathrm{CD}_{3}\right)_{2} \mathrm{CO}\right] \delta 7.11(\mathrm{~d}, J=1.9 \mathrm{~Hz}, 1 \mathrm{H}), 7.06(\mathrm{~d}, J=$ $1.9 \mathrm{~Hz}, 1 \mathrm{H}), 6.92(\mathrm{~d}, J=8.1 \mathrm{~Hz}, 1 \mathrm{H}), 6.90-6.85$ (complex m, $2 \mathrm{H}), 6.76(\mathrm{~d}, J=8.1 \mathrm{~Hz}, 1 \mathrm{H}), 6.52(\mathrm{dt}, J=15.8$ and $1.7 \mathrm{~Hz}$, $1 \mathrm{H}), 6.28(\mathrm{dt}, J=15.8$ and $5.3 \mathrm{~Hz}, 2 \mathrm{H}), 4.89(\mathrm{~d}, J=5.3 \mathrm{~Hz}$, $1 \mathrm{H}), 4.30(\mathrm{~m}, 1 \mathrm{H}), 4.19$ (dd, $J=5.3$ and $1.7 \mathrm{~Hz}, 2 \mathrm{H}), 3.85$ (s, $3 \mathrm{H}), 3.82(\mathrm{~s}, 3 \mathrm{H}), 3.79$ (partially obscured $\mathrm{m}, 1 \mathrm{H}), 3.69$ (dd, $J$ $=11.6$ and $4.0 \mathrm{~Hz}, 1 \mathrm{H}$ ) (signals due to three hydroxyl group protons not observed); ${ }^{1} \mathrm{H}$ NMR (400 $\left.\mathrm{MHz}, \mathrm{CD}_{3} \mathrm{OD}\right) \delta 7.02$ $(\mathrm{d}, J=2.0 \mathrm{~Hz}, 1 \mathrm{H}), 7.00(\mathrm{~s}, 1 \mathrm{H}), 6.87(\mathrm{~s}, 2 \mathrm{H}), 6.84$ (dd, $J=8.2$ and $2.0 \mathrm{~Hz}, 1 \mathrm{H}), 6.73(\mathrm{~d}, J=8.2 \mathrm{~Hz}, 1 \mathrm{H}), 6.51(\mathrm{dt}, J=15.7$ and $1.6 \mathrm{~Hz}, 1 \mathrm{H}), 6.24(\mathrm{dt}, J=15.7$ and $5.7 \mathrm{~Hz}, 1 \mathrm{H}), 4.83(\mathrm{~d}, J=5.7$ $\mathrm{Hz}, 1 \mathrm{H}), 4.36(\mathrm{~m}, 1 \mathrm{H}), 4.20(\mathrm{dd}, J=5.7$ and $1.6 \mathrm{~Hz}, 2 \mathrm{H}), 3.85$ $(\mathrm{dd}, J=12.0$ and $5.6 \mathrm{~Hz}, 1 \mathrm{H}), 3.80(\mathrm{~s}, 3 \mathrm{H}), 3.80(\mathrm{~s}, 3 \mathrm{H}), 3.76$ 
(partially obscured $\mathrm{d}, J=3.6 \mathrm{~Hz}, 1 \mathrm{H}$ ) (signals due to hydroxyl group protons not observed); ${ }^{13} \mathrm{C}$ NMR (100 $\left.\mathrm{MHz}, \mathrm{CD}_{3} \mathrm{OD}\right)$ $\delta$ see Table 1; IR $\nu_{\max } 3369,2918,1509,1266,1152,1122$, $1029 \mathrm{~cm}^{-1}$; MS (EI, +ve) $\mathrm{m} / z 376(15)\left(\mathrm{M}^{+\bullet}\right), 358(50), 328$ (45), 206 (100); HRMS calcd for $\mathrm{C}_{20} \mathrm{H}_{24} \mathrm{O}_{7}\left(\mathrm{M}^{+\bullet}\right)$ : 376.1522, found: 376.1524 .

Concentration of fraction $\mathrm{B}\left(t_{\mathrm{R}}=13.2 \mathrm{~min}\right)$ afforded compound $( \pm)-1^{41,10}(57 \mathrm{mg}, 73 \%)$ as a white powder. ${ }^{1} \mathrm{H}$ NMR $\left[300 \mathrm{MHz},\left(\mathrm{CD}_{3}\right)_{2} \mathrm{CO}\right] \delta 7.11(\mathrm{~d}, J=8.4 \mathrm{~Hz}, 1 \mathrm{H})$, 7.10-7.09 (complex m, 2H), 6.91 (dd, $J=8.4$ and $2.1 \mathrm{~Hz}, 1 \mathrm{H}$ ), $6.90(\mathrm{dd}, J=8.1$ and $1.9 \mathrm{~Hz}, 1 \mathrm{H}), 6.77(\mathrm{~d}, J=8.1 \mathrm{~Hz}, 1 \mathrm{H}), 6.54$ $(\mathrm{dt}, J=15.9$ and $1.7 \mathrm{~Hz}, 1 \mathrm{H}), 6.30(\mathrm{dt}, J=15.9$ and $5.3 \mathrm{~Hz}$, $1 \mathrm{H}), 4.88(\mathrm{~d}, J=6.3 \mathrm{~Hz}, 1 \mathrm{H}), 4.20(\mathrm{~m}, 3 \mathrm{H}), 3.90(\mathrm{~s}, 3 \mathrm{H}), 3.81$ (s, $3 \mathrm{H}), 3.68(\mathrm{dd}, J=11.8$ and $3.7 \mathrm{~Hz}, 1 \mathrm{H}), 3.50(\mathrm{dd}, J=11.8$ and $5.7 \mathrm{~Hz}, 1 \mathrm{H}$ ) (signals due to hydroxyl group protons not observed); ${ }^{1} \mathrm{H}$ NMR (400 MHz, $\left.\mathrm{CD}_{3} \mathrm{OD}\right) \delta 7.05$ (s, $1 \mathrm{H}$ ), 7.03 (s, $1 \mathrm{H}), 6.99(\mathrm{~d}, J=8.3 \mathrm{~Hz}, 1 \mathrm{H}), 6.90(\mathrm{~d}, J=8.3 \mathrm{~Hz}, 1 \mathrm{H}), 6.86$ $(\mathrm{d}, J=8.2 \mathrm{~Hz}, 1 \mathrm{H}), 6.76(\mathrm{~d}, J=8.2 \mathrm{~Hz}, 1 \mathrm{H}), 6.53(\mathrm{~d}, J=15.8$ $\mathrm{Hz}, 1 \mathrm{H}$ ), $6.25(\mathrm{dt}, J=15.8$ and $5.7 \mathrm{~Hz}, 1 \mathrm{H}$ ), 4.90 (partially obscured m, 1H), 4.31 (app. q, $J=5.0 \mathrm{~Hz}, 1 \mathrm{H}), 4.20$ (d, $J=5.7$ $\mathrm{Hz}, 2 \mathrm{H}), 3.87$ (s, 3H), 3.81 (s, 3H), $3.74(\mathrm{dd}, J=12.1,3.7 \mathrm{~Hz}$, $1 \mathrm{H}$ ), 3.48 (dd, $J=12.0,5.2 \mathrm{~Hz}, 1 \mathrm{H}$ ) (signals due to hydroxyl group protons not observed); ${ }^{13} \mathrm{C} \mathrm{NMR}\left(100 \mathrm{MHz}, \mathrm{CD}_{3} \mathrm{OD}\right)$ $\delta$ see Table 1; IR $\nu_{\max } 3369,2931,1604,1510,1263,1129$, 1079, 1029, $965 \mathrm{~cm}^{-1}$; MS (ESI, +ve) $\mathrm{m} / z 399$ (100) $[\mathrm{M}+$ $\mathrm{Na}]^{+}$; HRMS calcd for $\mathrm{C}_{20} \mathrm{H}_{24} \mathrm{NaO}_{7}[\mathrm{M}+\mathrm{Na}]^{+}$: 399.1420, found: 399.1420 .

2-(4-Allyl-2-methoxyphenoxy)acetic Acid (14). Compound 14 was prepared in $85 \%$ overall yield from ethyl $\alpha$ bromoacetate and eugenol (13) following a protocol reported by Spurg and Waldvogel ${ }^{25}$ to give a white, crystalline solid. ${ }^{1} \mathrm{H}$ NMR $\left(400 \mathrm{MHz}, \mathrm{CDCl}_{3}\right) \delta 6.91(\mathrm{~d}, J=7.9 \mathrm{~Hz}, 1 \mathrm{H}), 6.76(\mathrm{~m}$, $2 \mathrm{H}), 5.94(\mathrm{~m}, 1 \mathrm{H}), 5.11(\mathrm{~m}, 1 \mathrm{H}), 5.08(\mathrm{~m}, 1 \mathrm{H}), 4.63(\mathrm{~s}, 2 \mathrm{H})$, $3.90(\mathrm{~s}, 3 \mathrm{H}), 3.36(\mathrm{~d}, J=6.7 \mathrm{~Hz}, 2 \mathrm{H})$ (signal due to carboxylic acid group proton not observed); ${ }^{13} \mathrm{C}$ NMR (100 MHz, $\left.\mathrm{CDCl}_{3}\right) \delta 171.4,149.9,145.7,137.2,136.5,121.3,117.6,116.3$, 112.7, 69.0, 56.1, 40.0. These spectral data matched those reported by Labarrios and co-workers. ${ }^{26}$

(S)-3-(2-(4-Allyl-2-methoxyphenoxy)acetyl)-4-isopropyl5,5-diphenyloxazolidin-2-one (15). Oxalyl chloride $(710 \mu \mathrm{L}$, $8.14 \mathrm{mmol}$ ) was added dropwise over $0.08 \mathrm{~h}$ to a magnetically stirred solution of carboxylic acid $14(1.65 \mathrm{~g}, 7.40 \mathrm{mmol})$ and dimethylformamide (DMF) $(28 \mu \mathrm{L}, 0.37 \mathrm{mmol})$ in dichloromethane $(15 \mathrm{~mL})$ maintained at $0{ }^{\circ} \mathrm{C}$ under a nitrogen atmosphere. The ensuing mixture was allowed to warm to 22 ${ }^{\circ} \mathrm{C}$ and stirred until gas evolution ceased (ca. $1 \mathrm{~h}$ ). The dichloromethane was then removed by sparging the reaction mixture with a stream of nitrogen followed by further concentration of the reaction mixture under reduced pressure. The acid chloride thus obtained was dissolved in dry THF (15 $\mathrm{mL})$. In a separate flask, $n$-BuLi $(4.52 \mathrm{~mL}$ of a $1.5 \mathrm{M}$ solution in hexanes, $6.79 \mathrm{mmol}$ ) was added dropwise over $0.25 \mathrm{~h}$ to a magnetically stirred solution of $(S)$-4-isopropyl-5,5-diphenyloxazolidin-2-one $(12)^{14 \mathrm{~b}}(1.74 \mathrm{~g}, 6.17 \mathrm{mmol})$ in dry THF $(150$ $\mathrm{mL}$ ) maintained at $0{ }^{\circ} \mathrm{C}$. The resulting solution was stirred at this temperature for $0.5 \mathrm{~h}$ then cooled to $-78{ }^{\circ} \mathrm{C}$. The previously formed solution of the acid chloride in THF was then added dropwise over $0.25 \mathrm{~h}$, and stirring of the combined solutions continued at $-78{ }^{\circ} \mathrm{C}$ for $0.5 \mathrm{~h}$. The cooling bath was then removed, and the reaction mixture was allowed to warm to $22{ }^{\circ} \mathrm{C}$ and stirring was continued for $3 \mathrm{~h}$. After this time, the reaction mixture was cooled to $0{ }^{\circ} \mathrm{C}$ and quenched with $\mathrm{NH}_{4} \mathrm{Cl}$ (30 $\mathrm{mL}$ of a saturated aqueous solution) then acetic acid (5
$\mathrm{mL})$. The ensuing mixture was allowed to warm, over $0.25 \mathrm{~h}$, to $22{ }^{\circ} \mathrm{C}$ then it was extracted with ethyl acetate $(3 \times 30 \mathrm{~mL})$. The combined organic phases were washed with $\mathrm{NaHCO}_{3}(2 \times$ $10 \mathrm{~mL}$ of a saturated aqueous solution) and brine $(2 \times 20 \mathrm{~mL})$ before being dried $\left(\mathrm{Na}_{2} \mathrm{SO}_{4}\right)$, filtered, and concentrated under reduced pressure. The ensuing viscous, clear, and light-yellow oil was subjected to flash column chromatography (silica, hexane $\rightarrow 1: 4 \mathrm{v} / \mathrm{v}$ ethyl acetate/hexane gradient elution), and concentration of the appropriate fractions $\left(R_{\mathrm{f}}=0.3\right.$ in $1: 4 \mathrm{v} / \mathrm{v}$ ethyl acetate/hexane) afforded amide $15(2.79 \mathrm{~g}, 93 \%)$ as a white foam, $[\alpha]^{20}{ }_{\mathrm{D}}=-156\left(c=0.3, \mathrm{CHCl}_{3}\right) .{ }^{1} \mathrm{H}$ NMR (400 $\mathrm{MHz}_{\mathrm{CDCl}}$ ) $\delta$ 7.52-7.27 (complex m, 10H), 6.70 (d, $J=2.0$ $\mathrm{Hz}, 1 \mathrm{H}), 6.57(\mathrm{dd}, J=8.2$ and $2.0 \mathrm{~Hz}, 1 \mathrm{H}), 6.46(\mathrm{~d}, J=8.2 \mathrm{~Hz}$, $1 \mathrm{H}), 5.94(\mathrm{~m}, 1 \mathrm{H}), 5.37(\mathrm{~d}, J=3.3 \mathrm{~Hz}, 1 \mathrm{H}), 5.24(\mathrm{~d}, J=17.7$ $\mathrm{Hz}, 1 \mathrm{H}), 5.12-5.01$ (complex m, 3H), $3.82(\mathrm{~s}, 3 \mathrm{H}), 3.31$ (d, $J=$ $6.8 \mathrm{~Hz}, 2 \mathrm{H}), 2.00(\mathrm{~m}, 1 \mathrm{H}), 0.90(\mathrm{~d}, J=7.0 \mathrm{~Hz}, 3 \mathrm{H}), 0.79$ (d, $J$ $=6.8 \mathrm{~Hz}, 3 \mathrm{H}) ;{ }^{13} \mathrm{C} \mathrm{NMR}\left(100 \mathrm{MHz}, \mathrm{CDCl}_{3}\right) \delta 168.2,153.2$, $149.4,145.6,142.1,137.9,137.7,134.1,129.2,129.0,128.6$, $128.3,126.0,125.8,120.4,115.8,113.6,112.6,91.1,68.1,64.9$, 56.0, 40.0, 30.0, 21.9, 16.6; IR $\nu_{\max } 2969,1780,1724,1510$, 1257, 1209, 1178, 1147, 1035, 992, 733, $701 \mathrm{~cm}^{-1}$; MS (ESI, +ve) $m / z 508(100)[\mathrm{M}+\mathrm{Na}]^{+}$; HRMS calcd for $\mathrm{C}_{30} \mathrm{H}_{31} \mathrm{NNaO}_{5}[\mathrm{M}+\mathrm{Na}]^{+}:$508.2100, found: 508.2099.

(R)-3-(2-(4-Allyl-2-methoxyphenoxy)acetyl)-4-isopropyl5,5-diphenyloxazolidin-2-one (ent-15). Compound ent-15 was prepared in an analogous fashion to that described immediately above from compounds ent-12 and 14. Flash chromatographic purification then gave oxazolidin-2-one ent-15 $(8.79 \mathrm{~g}$, quantitative yield $)$ as a white foam, $[\alpha]_{\mathrm{D}}^{20}=+160(c=$ $\left.0.3, \mathrm{CHCl}_{3}\right)$. All the other spectral data acquired on this material were identical with those detailed above for compound 15.

(1R,2R)-2-(4-Allyl-2-methoxyphenoxy)-1-(4-((tertbutyldimethylsilyl)oxy)-3-methoxyphe-nyl)propane-1,3-diol (17). Step i: A magnetically stirred solution of amide 15 (2.00 g, $4.12 \mathrm{mmol})$ in dry dichloromethane $(8 \mathrm{~mL})$ maintained at $0{ }^{\circ} \mathrm{C}$ under a nitrogen atmosphere was treated, dropwise over $0.08 \mathrm{~h}$, with freshly prepared ${ }^{14 \mathrm{~b}} \mathrm{Bu}_{2}$ BOTf $(1.07 \mathrm{~mL}, 1.35 \mathrm{~g}, 4.94$ $\mathrm{mmol})$. The ensuing mixture was allowed to warm to $22^{\circ} \mathrm{C}$, stirred at this temperature for $0.25 \mathrm{~h}$, then freshly distilled Hünig's base $(970 \mu \mathrm{L}, 5.56 \mathrm{mmol})$ was added dropwise over $0.08 \mathrm{~h}$. Stirring was continued at $22{ }^{\circ} \mathrm{C}$ for another $0.5 \mathrm{~h}$ then the reaction mixture was cooled to $-78{ }^{\circ} \mathrm{C}$ before a solution of aldehyde $16^{27}$ (1.35 g, $\left.4.94 \mathrm{mmol}\right)$ in dichloromethane $(4 \mathrm{~mL})$ was added via syringe pump over $0.75 \mathrm{~h}$. The ensuing mixture was stirred at $-78{ }^{\circ} \mathrm{C}$ for a further $1 \mathrm{~h}$ then warmed to $0{ }^{\circ} \mathrm{C}$, stirred at this temperature for $4 \mathrm{~h}$, then quenched with phosphate buffer $(15 \mathrm{~mL}$ of a $1 \mathrm{M}$ aqueous solution at $\mathrm{pH} 7$ ) before being treated with methanol $/ 30 \%$ aq. hydrogen peroxide (10 mL of a $1: 1 \mathrm{v} / \mathrm{v}$ mixture) and allowed to warm to $22{ }^{\circ} \mathrm{C}$ over $1 \mathrm{~h}$. The biphasic mixture thus obtained was diluted with water $(20 \mathrm{~mL})$, and the separated aqueous layer was extracted with dichloromethane $(3 \times 10 \mathrm{~mL})$. The combined organic phases were washed with brine $(1 \times 10 \mathrm{~mL})$ then dried $\left(\mathrm{Na}_{2} \mathrm{SO}_{4}\right)$, filtered, and concentrated under reduced pressure. The ensuing thick oil was subjected to flash column chromatography (silica, dichloromethane $\rightarrow 1: 19 \mathrm{v} / \mathrm{v} \mathrm{Et}_{2} \mathrm{O} /$ dichloromethane gradient elution), and concentration of the appropriate fractions $\left(R_{\mathrm{f}}=0.5\right.$ in $1: 19 \mathrm{v} / \mathrm{v} \mathrm{Et}_{2} \mathrm{O} /$ dichloromethane) afforded the anticipated aldol product $(2.58 \mathrm{~g}, 83 \%)$ as a white foam, $[\alpha]^{20}{ }_{\mathrm{D}}=-78.5\left(c=1, \mathrm{CHCl}_{3}\right) .{ }^{1} \mathrm{H}$ NMR $(400$ $\mathrm{MHz}, \mathrm{CDCl}_{3}$ ) $\delta$ 7.36-7.27 (complex m, 10H), 6.87 (d, $J=2.0$ $\mathrm{Hz}, 1 \mathrm{H}), 6.71(\mathrm{~d}, J=8.2 \mathrm{~Hz}, 1 \mathrm{H}), 6.67(\mathrm{~d}, J=2.0 \mathrm{~Hz}, 1 \mathrm{H})$, 
$6.63(\mathrm{dd}, J=8.1$ and $2.0 \mathrm{~Hz}, 1 \mathrm{H}), 6.57(\mathrm{dd}, J=8.1$ and $2.0 \mathrm{~Hz}$, $1 \mathrm{H}), 6.48(\mathrm{~d}, J=8.1 \mathrm{~Hz}, 1 \mathrm{H}), 6.10(\mathrm{~m}, 1 \mathrm{H}), 5.89(\mathrm{~m}, 1 \mathrm{H}), 5.35$ $(\mathrm{d}, J=2.9 \mathrm{~Hz}, 1 \mathrm{H}), 5.05(\mathrm{~m} \mathrm{1H}), 5.01(\mathrm{~m}, 1 \mathrm{H}), 4.67(\mathrm{t}, J=5.0$ $\mathrm{Hz}, 1 \mathrm{H}), 3.79(\mathrm{~s}, 3 \mathrm{H}), 3.71(\mathrm{~s}, 3 \mathrm{H}), 3.28(\mathrm{~m}, 3 \mathrm{H}), 1.95(\mathrm{~m}$, $1 \mathrm{H}), 0.98(\mathrm{~s}, 9 \mathrm{H}), 0.86(\mathrm{~d}, J=7.0 \mathrm{~Hz}, 3 \mathrm{H}), 0.68(\mathrm{~d}, J=6.7 \mathrm{~Hz}$, $3 \mathrm{H}), 0.09$ (s, 3H), $0.08(\mathrm{~s}, 3 \mathrm{H}) ;{ }^{13} \mathrm{C}$ NMR $\left(100 \mathrm{MHz} \mathrm{CDCl}_{3}\right)$ $\delta 169.3,152.9,150.7,150.4,145.5,144.7,141.6,138.1,137.5$, $135.6,131.9,129.0(3), 129.0(0), 128.5,128.1,125.9,125.4$, $120.8,120.5,119.3,118.5,115.9,113.1,110.6,90.1,81.4,74.0$, 65.1, 56.0, 55.3, 40.0, 30.1, 25.9, 21.8, 18.6, 16.3, -4.5, -4.6; IR $\nu_{\max } 3452,2954,2930,2858,1777,1716,1510,1450,1369$, 1283, 1210, 1153, 1035, 908, $702 \mathrm{~cm}^{-1}$; MS (ESI, +ve) $\mathrm{m} / z$ $774(100)[\mathrm{M}+\mathrm{Na}]^{+}$; HRMS calcd for $\mathrm{C}_{44} \mathrm{H}_{53} \mathrm{NNaO}_{8} \mathrm{Si}[\mathrm{M}+$ $\mathrm{Na}]^{+}:$774.3438, found: 774.3433 .

Step ii: Methanol $(230 \mu \mathrm{L}, 5.65 \mathrm{mmol})$ was added to a magnetically stirred solution of the above-mentioned aldol product $(1.70 \mathrm{~g}, 2.26 \mathrm{mmol})$ in THF $(25 \mathrm{~mL})$ maintained under nitrogen at $22{ }^{\circ} \mathrm{C}$. The resulting solution was cooled to 0 ${ }^{\circ} \mathrm{C}$, and lithium borohydride (123 mg, $5.65 \mathrm{mmol}$ ) was then added in portions over $0.08 \mathrm{~h}$. The ensuing mixture was stirred at $0{ }^{\circ} \mathrm{C}$ for $0.5 \mathrm{~h}$ then warmed to $22{ }^{\circ} \mathrm{C}$ and stirred at this temperature for $2 \mathrm{~h}$ before being quenched with $\mathrm{NH}_{4} \mathrm{Cl}(20$ $\mathrm{mL}$ of a saturated aqueous solution) then diluted with $\mathrm{Et}_{2} \mathrm{O}$ $(100 \mathrm{~mL})$. The separated aqueous layer was extracted with $\mathrm{Et}_{2} \mathrm{O}(2 \times 20 \mathrm{~mL})$, and the combined organic extracts were washed with brine $(2 \times 20 \mathrm{~mL})$ then dried $\left(\mathrm{Na}_{2} \mathrm{SO}_{4}\right)$, filtered, and concentrated under reduced pressure. The ensuing paleyellow residue was subjected to flash column chromatography (silica, 1:19 v/v Et ${ }_{2} \mathrm{O} /$ dichloromethane $\rightarrow$ 1:4 v/v $\mathrm{Et}_{2} \mathrm{O} /$ dichloromethane gradient elution), and concentration of the appropriate fractions $\left(R_{\mathrm{f}}=0.4\right.$ in $1: 4 \mathrm{v} / \mathrm{v} \mathrm{Et}_{2} \mathrm{O} /$ dichloromethane) afforded diol $17(982 \mathrm{mg}, 92 \%)$ as a clear, colorless oil, $[\alpha]_{\mathrm{D}}^{20}=-63.3\left(c=0.8, \mathrm{CHCl}_{3}\right) .{ }^{1} \mathrm{H}$ NMR $(400 \mathrm{MHz}$, $\left.\mathrm{CDCl}_{3}\right) \delta 7.01(\mathrm{~d}, J=8.0 \mathrm{~Hz}, 1 \mathrm{H}), 6.95(\mathrm{~d}, J=1.9 \mathrm{~Hz}, 1 \mathrm{H})$, $6.88(\mathrm{dd}, J=8.1$ and $1.9 \mathrm{~Hz}, 1 \mathrm{H}), 6.82(\mathrm{~d}, J=8.1 \mathrm{~Hz}, 1 \mathrm{H}), 6.76$ $(\mathrm{d}, J=1.9 \mathrm{~Hz}, 1 \mathrm{H}), 6.74(\mathrm{dd}, J=8.0$ and $1.9 \mathrm{~Hz}, 1 \mathrm{H}), 5.95(\mathrm{~m}$, $1 \mathrm{H}), 5.11(\mathrm{~m}, 1 \mathrm{H}), 5.07(\mathrm{t}, J=1.4 \mathrm{~Hz}, 1 \mathrm{H}), 4.95(\mathrm{~d}, J=8.0 \mathrm{~Hz}$, $1 \mathrm{H}), 3.97(\mathrm{dt}, J=7.6$ and $3.6 \mathrm{~Hz}, 1 \mathrm{H}), 3.90(\mathrm{~s}, 3 \mathrm{H}), 3.80(\mathrm{~s}$, $3 \mathrm{H}$ ), $3.60(\mathrm{dd}, J=12.5$ and $3.2 \mathrm{~Hz}, 1 \mathrm{H}), 3.47(\mathrm{dd}, J=12.5$ and $4.0 \mathrm{~Hz}, 1 \mathrm{H}), 3.35$ (d, $J=6.8 \mathrm{~Hz}, 2 \mathrm{H}), 0.99$ (s, 9H), 0.14 (s, $6 \mathrm{H})$ (signals due to hydroxyl group protons not observed); ${ }^{13} \mathrm{C}$ NMR $\left(100 \mathrm{MHz}, \mathrm{CDCl}_{3}\right) \delta 151.3,151.2,146.0,145.1,137.3$, 136.5, 133.2, 121.7, 121.2, 119.8, 116.2, 112.6, 110.8, 90.0, 74.2, $61.3,56.0,55.6,40.1,25.9,18.6,-4.5(0),-4.5(2)$ (one signal obscured or overlapping); IR $\nu_{\max } 3453,2954,2931,2857$, 1510, 1465, 1419, 1283, 1264, 1228, 1156, 1034, 911, 840, 782 $\mathrm{cm}^{-1}$; MS (ESI, +ve) $\mathrm{m} / z$ (\%) 497 (100) $[\mathrm{M}+\mathrm{Na}]^{+}$; HRMS calcd for $\mathrm{C}_{26} \mathrm{H}_{38} \mathrm{NaO}_{6} \mathrm{Si}[\mathrm{M}+\mathrm{Na}]^{+}$: 497.2335, found: 497.2332.

(1S,2S)-2-(4-Allyl-2-methoxyphenoxy)-1-(4-((tertbutyldimethylsilyl)oxy)-3-methoxyphen-yl)propane-1,3-diol (ent-17). Diol ent-17 was prepared as described immediately above from precursor ent-15 and aldehyde 16. Flash chromatographic purification of the product from step $i$ gave the expected aldol product $(2.15 \mathrm{~g}, 69 \%)$ as a clear, colorless oil, $[\alpha]_{\mathrm{D}}^{20}=+77.7\left(c=1, \mathrm{CHCl}_{3}\right)$. All the other spectral data acquired on this material were identical with those reported above for the product from step i. The conditions defined in step ii above were employed to produce diol ent-17 (684 mg, $96 \%)$, which was obtained as a clear, colorless oil, $[\alpha]_{\mathrm{D}}^{20}=$ $+66.2\left(c=0.7, \mathrm{CHCl}_{3}\right)$. All other spectral data acquired on this material were identical with those reported above for compound 17.
(E)-3-(4-(((1R,2R)-1-(4-((tert-Butyldimethylsilyl)oxy)-3-methoxyphenyl)-1,3-dihydroxypr-oxypropan-2-yl)oxy)-3methoxyphenyl)allyl Acetate (18). Acetic acid (370 $\mu \mathrm{L}, 6.5$ $\mathrm{mmol})$, sodium acetate $(6.5 \mathrm{mg}, 0.08 \mathrm{mmol})$, molecular sieves (2 mg of activated $4 \AA$ material), 4,5-DAF ( $5.1 \mathrm{mg}, 7 \mathrm{~mol} \%$ ), and $\mathrm{Pd}(\mathrm{OAc})_{2}(6.3 \mathrm{mg}, 7 \mathrm{~mol} \%)$ were added sequentially to a magnetically stirred solution of compound $17(190 \mathrm{mg}, 0.40$ $\mathrm{mmol})$ in 1,4-dioxane $(2.4 \mathrm{~mL})$ maintained at $22{ }^{\circ} \mathrm{C}$. Oxygen from a balloon was bubbled through the resulting solution for $0.25 \mathrm{~h}$, which was then heated to $60{ }^{\circ} \mathrm{C}$ and maintained under an atmosphere of oxygen. After $48 \mathrm{~h}$, the reaction mixture was cooled to $22{ }^{\circ} \mathrm{C}$, and the solvent was removed under reduced pressure. The black residue thus obtained was subjected to flash column chromatography (silica, hexane $\rightarrow$ 3:2 v/v ethyl acetate/hexane gradient elution), and concentration of the appropriate fractions $\left(R_{\mathrm{f}}=0.2\right.$ in $1: 1 \mathrm{v} / \mathrm{v}$ EtOAc/hexane) afforded acetate $18(103 \mathrm{mg}, 48 \%)$ as a pale-yellow oil, $[\alpha]_{\mathrm{D}}^{20}=$ -69.1 $\left(c=0.6, \mathrm{CHCl}_{3}\right) .{ }^{1} \mathrm{H}$ NMR $\left(400 \mathrm{MHz}, \mathrm{CDCl}_{3}\right) \delta 7.04$ (d, $J=8.2 \mathrm{~Hz}, 1 \mathrm{H}), 7.01-6.92$ (complex m, 3H), 6.87 (dd, $J=$ 8.0 and $1.9 \mathrm{~Hz}, 1 \mathrm{H}), 6.83(\mathrm{~d}, J=8.0 \mathrm{~Hz}, 1 \mathrm{H}), 6.60(\mathrm{~d}, J=15.9$ $\mathrm{Hz}, 1 \mathrm{H}), 6.21(\mathrm{dt}, J=15.9$ and $6.5 \mathrm{~Hz}, 1 \mathrm{H}), 4.95(\mathrm{dd}, J=7.9$ and $2.0 \mathrm{~Hz}, 1 \mathrm{H}), 4.72(\mathrm{dd}, J=6.5$ and $1.3 \mathrm{~Hz}, 2 \mathrm{H}), 4.03(\mathrm{~m}$, $1 \mathrm{H}), 3.93(\mathrm{~s}, 3 \mathrm{H}), 3.80(\mathrm{~s}, 3 \mathrm{H}), 3.61(\mathrm{~m}, 1 \mathrm{H}), 3.55-3.46$ (complex m, 2H), $2.57(\mathrm{~m}, 1 \mathrm{H}), 2.11(\mathrm{~s}, 3 \mathrm{H}), 0.99(\mathrm{~s}, 9 \mathrm{H})$, $0.14(\mathrm{~s}, 6 \mathrm{H}) ;{ }^{13} \mathrm{C}$ NMR $\left(100 \mathrm{MHz}, \mathrm{CDCl}_{3}\right) \delta 171.0,151.4$, $151.3,147.9,145.2,133.8,133.1,132.6,122.9,121.0,120.9$, $120.5,119.7,110.8,110.0,89.7,74.2,65.1,61.4,56.1,55.7$, $25.9,21.2,18.6,-4.5(0),-4.5(2)$; IR $\nu_{\max } 3467,2952,2933$, 2857, 1739, 1510, 1465, 1419, 1251, 1232, 1158, 1128, 1030, 908, $840 \mathrm{~cm}^{-1}$; MS (ESI, +ve) $\mathrm{m} / z 555(100)[\mathrm{M}+\mathrm{Na}]^{+}$; HRMS calcd for $\mathrm{C}_{28} \mathrm{H}_{40} \mathrm{NaO}_{8} \mathrm{Si}[\mathrm{M}+\mathrm{Na}]^{+}: 555.2390$, found: 555.2390 .

(E)-3-(4-(((1S,2S)-1-(4-((tert-Butyldimethylsilyl)oxy)-3-methoxyphenyl)-1,3-dihydroxypro-pan-2-yl)oxy)-3methoxyphenyl)allyl Acetate (ent-18). Allylic oxidation of compound ent-17 in the same manner as that described above for congener 17 afforded, after flash chromatographic purification, compound ent-18 (71 $\mathrm{mg}, 65 \%)$ as a pale-yellow oil, $[\alpha]_{D}^{20}=+47.5\left(c=1.6, \mathrm{CHCl}_{3}\right)$. All other spectral data acquired on this material were identical with those reported above for compound $\mathbf{1 8}$.

(1R,2R)-1-(4-Hydroxy-3-methoxyphenyl)-2-(4-((E)-3-hydroxyprop-1-en-1-yl)-2-methox-yphenoxy)propane-1,3-diol (ent-1). $\mathrm{K}_{2} \mathrm{CO}_{3}(270 \mathrm{mg}, 1.95 \mathrm{mmol})$ was added to a magnetically stirred solution of acetate $18(45 \mathrm{mg}, 0.085$ $\mathrm{mmol})$ in methanol $(5 \mathrm{~mL})$ containing water $(100 \mu \mathrm{L})$ and maintained at $22{ }^{\circ} \mathrm{C}$ under a nitrogen atmosphere. The ensuing mixture was stirred at this temperature for $18 \mathrm{~h}$ then diluted with ethyl acetate $(20 \mathrm{~mL})$, acidified (to $\mathrm{pH} 5)$ using acetic acid (ca. $200 \mu \mathrm{L})$, then washed with water $(1 \times 5 \mathrm{~mL})$ and brine $(2$ $\times 5 \mathrm{~mL})$ before being dried $\left(\mathrm{Na}_{2} \mathrm{SO}_{4}\right)$, filtered, and concentrated under reduced pressure. The ensuing pale-yellow oil was subjected to flash column chromatography (silica, 1:19 $\mathrm{v} / \mathrm{v}$ methanol/dichloromethane $\rightarrow 1: 9 \mathrm{v} / \mathrm{v}$ methanol/dichloromethane gradient elution). Concentration of the appropriate fractions $\left(R_{\mathrm{f}}=0.2\right.$ in $1: 19 \mathrm{v} / \mathrm{v}$ methanol/dichloromethane) afforded compound ent-1 (25 mg, 79\%) as a clear, colorless gum, $[\alpha]_{\mathrm{D}}^{20}=-36.7\left(c=0.9\right.$, methanol). ${ }^{1} \mathrm{H}$ NMR $(400 \mathrm{MHz}$, $\left.\mathrm{CD}_{3} \mathrm{OD}\right) \delta 7.06(\mathrm{~s}, 1 \mathrm{H}), 7.03(\mathrm{~s}, 1 \mathrm{H}), 7.00(\mathrm{~d}, J=8.3 \mathrm{~Hz}, 1 \mathrm{H})$, $6.91(\mathrm{~d}, J=8.3 \mathrm{~Hz}, 1 \mathrm{H}), 6.86(\mathrm{~d}, J=8.2 \mathrm{~Hz}, 1 \mathrm{H}), 6.75(\mathrm{dd}, J=$ 8.2 and $1.4 \mathrm{~Hz}, 1 \mathrm{H}), 6.53(\mathrm{~d}, J=16.0 \mathrm{~Hz}, 1 \mathrm{H}), 6.26(\mathrm{dt}, J=$ 16.0 and $5.4 \mathrm{~Hz}, 1 \mathrm{H}), 4.88(\mathrm{~m}, 1 \mathrm{H}), 4.29(\mathrm{~m}, 1 \mathrm{H}), 4.20(\mathrm{~d}, J=$ $5.7 \mathrm{~Hz}, 2 \mathrm{H}), 3.88(\mathrm{~s}, 3 \mathrm{H}), 3.82(\mathrm{~s}, 3 \mathrm{H}), 3.73(\mathrm{dd}, J=11.9$ and 
$4.0 \mathrm{~Hz}, 1 \mathrm{H}$ ), 3.47 (dd, $J=11.9$ and $5.4 \mathrm{~Hz}, 1 \mathrm{H}$ ) (signals due to hydroxyl group protons not observed); ${ }^{13} \mathrm{C}$ NMR (100 MHz, $\left.\mathrm{CD}_{3} \mathrm{OD}\right) \delta 151.8,149.2,148.8,147.2,133.8,133.1,131.4$, 128.6, 120.8, 120.7, 118.8, 115.8, 111.7, 111.3, 87.1, 74.0, 63.8, $61.9,56.5,56.3$; IR $\nu_{\max } 3348,2934,1602,1509,1464,1263$, 1226, 1156, 1130, 1027, $968 \mathrm{~cm}^{-1}$; MS (ESI, +ve) $\mathrm{m} / z 399$ (100) $[\mathrm{M}+\mathrm{Na}]^{+}$; HRMS calcd for $\mathrm{C}_{20} \mathrm{H}_{24} \mathrm{NaO}_{7}[\mathrm{M}+\mathrm{Na}]^{+}$: 399.1420, found: 399.1419; HPLC analysis: Trefoil CEL1 column, $98: 2 \mathrm{v} / \mathrm{v}$ methanol/supercritical $\mathrm{CO}_{2}$ elution, flow rate $2 \mathrm{~mL} / \mathrm{min}$, temperature $40{ }^{\circ} \mathrm{C}$, detection at $\lambda=254 \mathrm{~nm}, t_{\text {major }}=$ $6.03 \mathrm{~min}$, ee $>99 \%$.

(1S,2S)-1-(4-Hydroxy-3-methoxyphenyl)-2-(4-((E)-3-hydroxyprop-1-en-1-yl)-2-methoxy-phenoxy)propane-1,3-diol (1). Treatment of acetate ent-18 with potassium carbonate in the same manner as that described above gave neolignan 1 (28 $\mathrm{mg}, 93 \%)$ as a clear, colorless gum, $[\alpha]_{\mathrm{D}}^{20}=+32.4(c=0.2$, methanol). All other spectral data acquired on this material were identical with those reported above for compound ent-1. HPLC analysis: Trefoil CEL1 column, 98:2 v/v methanol/ supercritical $\mathrm{CO}_{2}$ elution, flow rate $2 \mathrm{~mL} / \mathrm{min}$, temperature 40 ${ }^{\circ} \mathrm{C}$, detection at $\lambda=254 \mathrm{~nm}, t_{\text {minor }}=5.86 \mathrm{~min}, t_{\text {major }}=6.05 \mathrm{~min}$, ee $=90 \%$.

4-((1R,2R)-2-(4-Allyl-2-methoxyphenoxy)-3-((tertbutyldimethylsilyl)oxy)-1-hydroxyprop-yl)-2-methoxyphenol (19). The following one-pot procedure for preparing compound 19 was established after that used to prepare its enantiomer (ent-19) and proved to be the more efficient one. Thus, a magnetically stirred solution of diol $17(565 \mathrm{mg}, 1.19$ mmol) in DMF ( $4 \mathrm{~mL}$ ) was cooled to $0{ }^{\circ} \mathrm{C}$ and treated sequentially with imidazole $(162 \mathrm{mg}, 2.38 \mathrm{mmol})$ and TBDMS$\mathrm{Cl}$ (194 mg, $1.25 \mathrm{mmol}$ ). The ice bath was then removed, and the resulting solution was stirred at $22{ }^{\circ} \mathrm{C}$ for $1.5 \mathrm{~h}$ before being treated with $\mathrm{Cs}_{2} \mathrm{CO}_{3}(774 \mathrm{mg}, 3.38 \mathrm{mmol})$ and water $(400 \mu \mathrm{L})$. The resulting mixture was stirred at $22{ }^{\circ} \mathrm{C}$ for $2 \mathrm{~h}$ then heated at $40{ }^{\circ} \mathrm{C}$ for $4 \mathrm{~h}$. The cooled reaction mixture was stirred at 22 ${ }^{\circ} \mathrm{C}$ for $16 \mathrm{~h}$ before being diluted with ethyl acetate $(30 \mathrm{~mL})$ and washed with $\mathrm{NH}_{4} \mathrm{Cl}(3 \times 10 \mathrm{~mL}$ of a saturated aqueous solution). The combined aqueous phases were extracted with ethyl acetate $(3 \times 10 \mathrm{~mL})$ and the combined organic phases washed with brine $(2 \times 10 \mathrm{~mL})$ then dried $\left(\mathrm{Na}_{2} \mathrm{SO}_{4}\right)$, filtered, and concentrated under reduced pressure. The resulting paleyellow residue was subjected to flash column chromatography (silica, 1:9 v/ $\mathrm{v} \mathrm{Et}_{2} \mathrm{O} /$ dichloromethane), and concentration of the appropriate fractions $\left(R_{\mathrm{f}}=0.2\right.$ in $1: 19 \mathrm{v} / \mathrm{v} \mathrm{Et} \mathrm{Et}_{2} \mathrm{O} /$ dichloromethane) afforded phenol $19(544 \mathrm{mg}, 96 \%)$ as a clear, colorless oil, $[\alpha]_{\mathrm{D}}^{20}=-103\left(c=1, \mathrm{CHCl}_{3}\right) .{ }^{1} \mathrm{H}$ NMR $\left(400 \mathrm{MHz}, \mathrm{CDCl}_{3}\right) \delta 7.11(\mathrm{~d}, J=8.1 \mathrm{~Hz}, 1 \mathrm{H}), 6.93(\mathrm{~s}, 1 \mathrm{H})$, $6.87(\mathrm{~m}, 2 \mathrm{H}), 6.74(\mathrm{~d}, J=2.0 \mathrm{~Hz}, 1 \mathrm{H}), 6.71(\mathrm{dd}, J=8.1$ and 2.0 $\mathrm{Hz}, 1 \mathrm{H}), 5.96(\mathrm{~m}, 1 \mathrm{H}), 5.10(\mathrm{~m}, 1 \mathrm{H}), 5.07(\mathrm{~m}, 1 \mathrm{H}), 4.82(\mathrm{dd}, J$ $=7.7$ and $2.6 \mathrm{~Hz}, 1 \mathrm{H}), 4.21(\mathrm{~d}, J=2.6 \mathrm{~Hz}, 1 \mathrm{H}), 4.03(\mathrm{~m}, 1 \mathrm{H})$, $3.88(\mathrm{~s}, 3 \mathrm{H}), 3.86(\mathrm{~s}, 3 \mathrm{H}), 3.72(\mathrm{dd}, J=11.2$ and $3.4 \mathrm{~Hz}, 1 \mathrm{H})$, $3.63(\mathrm{dd}, J=11.2$ and $5.4 \mathrm{~Hz}, 1 \mathrm{H}), 3.37(\mathrm{~d}, J=6.8 \mathrm{~Hz}, 2 \mathrm{H})$, $0.88(\mathrm{~s}, 9 \mathrm{H}), 0.00(\mathrm{~s}, 3 \mathrm{H}),-0.01(\mathrm{~s}, 3 \mathrm{H})$ (signal due to one hydroxyl group protons not observed); ${ }^{13} \mathrm{C}$ NMR (100 MHz, $\left.\mathrm{CDCl}_{3}\right) \delta 150.7$, 147.0, 146.6, 145.5, 137.6, 135.4, 132.4, 121.1, 120.6, 120.3, 116.0, 114.2, 112.4, 109.6, 89.0, 74.0, 62.7, 56.1, $55.9,40.1,26.0,18.5,-5.3(0),-5.3(4)$; IR $\nu_{\max } 3466,2954$, 2930, 2856, 1606, 1509, 1454, 1266, 1227, 1127, 1035, 836, $779 \mathrm{~cm}^{-1}$; MS (ESI, +ve) $\mathrm{m} / z(\%)=497(100)[\mathrm{M}+\mathrm{Na}]^{+}$; HRMS calcd for $\mathrm{C}_{26} \mathrm{H}_{38} \mathrm{NaO}_{6} \mathrm{Si}[\mathrm{M}+\mathrm{Na}]^{+}:$497.2335, found: 497.2334.

4-((1S,2S)-2-(4-Allyl-2-methoxyphenoxy)-3-((tertbutyldimethylsilyl)oxy)-1-hydroxypropy-l)-2-methoxyphenol (ent-19). A magnetically stirred solution of diol ent-17 $(452 \mathrm{mg}$, $0.95 \mathrm{mmol})$ in dichloromethane $(6 \mathrm{~mL})$ was cooled to $-5{ }^{\circ} \mathrm{C}$ and treated sequentially with imidazole $(129 \mathrm{mg}, 1.9 \mathrm{mmol})$ and TBDMS-Cl (155 mg, $1.00 \mathrm{mmol})$. The cooling bath was then removed, and the reaction mixture was stirred at $22{ }^{\circ} \mathrm{C}$ for $16 \mathrm{~h}$ before being quenched with $\mathrm{NH}_{4} \mathrm{Cl}(10 \mathrm{~mL}$ of a saturated aqueous solution). The separated aqueous phase was extracted with dichloromethane $(3 \times 10 \mathrm{~mL})$ and the combined organic phases were then washed with brine $(2 \times 10 \mathrm{~mL})$ before being dried $\left(\mathrm{Na}_{2} \mathrm{SO}_{4}\right)$, filtered, and concentrated under reduced pressure to give the anticipated bis-TBDMS ether $(386 \mathrm{mg})$ as a light-yellow oil. This oil was dissolved in DMF $(1 \mathrm{~mL})$, and the resulting solution was treated with $\mathrm{Cs}_{2} \mathrm{CO}_{3}(307 \mathrm{mg}, 0.95$ $\mathrm{mmol})$ and water $(100 \mu \mathrm{L})$ then stirred at $22{ }^{\circ} \mathrm{C}$ for $24 \mathrm{~h}$. After this time, another batch of $\mathrm{Cs}_{2} \mathrm{CO}_{3}(200 \mathrm{mg}, 0.62 \mathrm{mmol})$ was added, and stirring continued for an additional $24 \mathrm{~h}$. The reaction mixture was then diluted with ethyl acetate $(30 \mathrm{~mL})$ before being washed with $\mathrm{NH}_{4} \mathrm{Cl}(3 \times 10 \mathrm{~mL}$ of a saturated aqueous solution). The combined aqueous washings were extracted with ethyl acetate $(3 \times 10 \mathrm{~mL})$, and the combined organic phases were then washed with brine $(2 \times 10 \mathrm{~mL})$ before being dried $\left(\mathrm{Na}_{2} \mathrm{SO}_{4}\right)$, filtered, and concentrated under reduced pressure. The ensuing pale-yellow residue was subjected to flash column chromatography (silica, 1:9 v/v $\mathrm{Et}_{2} \mathrm{O}$ /dichloromethane), and concentration of the appropriate fractions $\left(R_{\mathrm{f}}=0.2\right.$ in $\left.1: 19 \mathrm{v} / \mathrm{v} \mathrm{Et}_{2} \mathrm{O} / \mathrm{DCM}\right)$ afforded phenol ent-19 (232 mg, 51\% over two steps) as a clear, colorless oil, $[\alpha]^{20}{ }_{\mathrm{D}}=+98.8\left(c=0.7, \mathrm{CHCl}_{3}\right)$. All other spectral data acquired on this material were identical with those reported above for compound 19.

4-((1R,2R)-2-(4-Allyl-2-methoxyphenoxy)-3-((tertbutyldimethylsilyl)oxy)-1-hydroxyprop-yl)-2-methoxyphenyl 4-Methylbenzenesulfonate (20). p-Toluenesulfonyl chloride $(216 \mathrm{mg}, 1.13 \mathrm{mmol})$ was added in one portion to a magnetically stirred solution of phenol $19(512 \mathrm{mg}, 1.08$ $\mathrm{mmol})$ and triethylamine $(225 \mu \mathrm{L}, 1.62 \mathrm{mmol})$ in dichloromethane $(50 \mathrm{~mL})$ maintained at $0{ }^{\circ} \mathrm{C}$. DMAP $(6.6 \mathrm{mg}, 0.05$ $\mathrm{mmol}$ ) was then added to the reaction mixture, and stirring was continued at $0{ }^{\circ} \mathrm{C}$ for $1 \mathrm{~h}$. The resulting mixture was quenched with $\mathrm{NH}_{4} \mathrm{Cl}(20 \mathrm{~mL}$ of an aqueous solution), and the separated aqueous layer was extracted with dichloromethane $(2 \times 10$ $\mathrm{mL})$. The combined organic phases were washed with brine $(2$ $\times 15 \mathrm{~mL}$ ) before being dried $\left(\mathrm{Na}_{2} \mathrm{SO}_{4}\right)$, filtered, and concentrated under reduced pressure. The pale-yellow oil thus obtained was subjected to flash column chromatography (silica, $1: 24 \mathrm{v} / \mathrm{v} \mathrm{Et}_{2} \mathrm{O} /$ dichloromethane), and concentration of the appropriate fractions $\left(R_{\mathrm{f}}=0.6\right.$ in $1: 19 \mathrm{v} / \mathrm{v} \mathrm{Et} \mathrm{Et}_{2} \mathrm{O} /$ dichloromethane) afforded phenol $20(590 \mathrm{mg}, 87 \%)$ as a clear, colorless oil, $[\alpha]_{\mathrm{D}}^{20}=-54.2\left(c=1.1, \mathrm{CHCl}_{3}\right) .{ }^{1} \mathrm{H}$ NMR $\left(400 \mathrm{MHz}, \mathrm{CDCl}_{3}\right) \delta 7.72(\mathrm{~d}, J=8.3 \mathrm{~Hz}, 2 \mathrm{H}), 7.26(\mathrm{~d}, J=8.3$ $\mathrm{Hz}, 2 \mathrm{H}), 7.10(\mathrm{~d}, J=8.0 \mathrm{~Hz}, 1 \mathrm{H}), 7.02(\mathrm{~d}, J=8.0 \mathrm{~Hz}, 1 \mathrm{H})$, 6.94-6.88 (complex m, 2H), 6.73-6.67 (complex m, 2H), 5.95 $(\mathrm{m}, 1 \mathrm{H}), 5.12-5.18($ complex m 1H), $5.06(\mathrm{~m}, 1 \mathrm{H}), 4.89(\mathrm{dd}, J$ $=7.0$ and $3.2 \mathrm{~Hz}, 1 \mathrm{H}), 4.24(\mathrm{~d}, J=3.2 \mathrm{~Hz}, 1 \mathrm{H}), 4.01(\mathrm{~m}, 1 \mathrm{H})$, $3.85(\mathrm{~s}, 3 \mathrm{H}), 3.73(\mathrm{dd}, J=11.2$ and $3.8 \mathrm{~Hz}, 1 \mathrm{H}), 3.62(\mathrm{dd}, J=$ 11.2 and $4.9 \mathrm{~Hz}, 1 \mathrm{H}), 3.51(\mathrm{~s}, 3 \mathrm{H}), 3.34(\mathrm{~d}, J=6.7 \mathrm{~Hz}, 2 \mathrm{H})$, 2.42 (s, 3H), 0.89 (s, 9H), 0.02 (s, 3H), 0.01 (s, 3H); ${ }^{13} \mathrm{C}$ NMR $\left(100 \mathrm{MHz}, \mathrm{CDCl}_{3}\right) \delta 151.6,150.6,146.4,144.9,140.7,137.8$, $137.3,135.6,133.2,129.3,128.7,123.6,121.0,120.0,119.3$, $115.9,112.4,111.3,87.8,73.4,62.3,55.7,55.5,39.9,25.9,21.7$, $18.3,-5.5$ (one signal obscured or overlapping); IR $\nu_{\max } 3475$, 2951, 2931, 2856, 1600, 1506, 1464, 1419, 1264, 1176, 1092, 1035, 837, $779 \mathrm{~cm}^{-1}$; MS (ESI, +ve) $\mathrm{m} / z 651$ (100) $[\mathrm{M}+$ 
$\mathrm{Na}]^{+}$; HRMS calcd for $\mathrm{C}_{33} \mathrm{H}_{44} \mathrm{NaO}_{8} \mathrm{SSi}[\mathrm{M}+\mathrm{Na}]^{+}: 651.2424$, found: 651.2423 .

4-((1S,2S)-2-(4-Allyl-2-methoxyphenoxy)-3-((tertbutyldimethylsilyl)oxy)-1-hydroxypropy-I)-2-methoxyphenyl 4-Methylbenzenesulfonate (ent-20). Treatment of compound ent-19 with $p$-toluenesulfonyl chloride, $\mathrm{Et}_{3} \mathrm{~N}$, and DMAP in the same manner as that described immediately above gave ester ent-20 $(252 \mathrm{mg}, 91 \%)$ as a clear, colorless oil, $[\alpha]_{\mathrm{D}}^{20}=+58.4(c$ $=0.8, \mathrm{CHCl}_{3}$ ). All other spectral data acquired on this material were identical with those reported above for compound 20.

(1S,2R)-2-(4-Allyl-2-methoxyphenoxy)-3-((tertbutyldimethylsilyl)oxy)-1-(3-methoxy-4-(tosyloxy)phenyl)propyl 4-Nitrobenzoate (21). A magnetically stirred solution of compound 20 ( $580 \mathrm{mg}, 0.92 \mathrm{mmol}$ ), triphenylphosphine (290 $\mathrm{mg}, 1.11 \mathrm{mmol})$, and $p$-nitrobenzoic acid $(185 \mathrm{mg}, 1.11 \mathrm{mmol})$ in dry THF $(40 \mathrm{~mL})$ was cooled to $-10{ }^{\circ} \mathrm{C}$, and DEAD $(180$ $\mu \mathrm{L}, 1.11 \mathrm{mmol}$ ) was then added to the reaction mixture over $0.25 \mathrm{~h}$. The resulting solution was stirred at $-10{ }^{\circ} \mathrm{C}$ for $0.5 \mathrm{~h}$ before being warmed to $22^{\circ} \mathrm{C}$, and stirring then continued for an additional $16 \mathrm{~h}$. The resulting solution was concentrated under reduced pressure, and the light-yellow solid thus obtained was subjected to flash chromatography (silica, hexane $\rightarrow 3: 17 \mathrm{v} / \mathrm{v}$ ethyl acetate/hexane gradient elution). Concentration of the relevant fractions $\left(R_{\mathrm{f}}=0.3\right.$ in $1: 4 \mathrm{v} /$ ethyl acetate/ hexane) afforded $p$-nitrobenzoate $21(602 \mathrm{mg}, 84 \%)$ as a white, crystalline solid, $\mathrm{mp}=107-108{ }^{\circ} \mathrm{C},[\alpha]_{\mathrm{D}}^{20}=-4.3(c=1.2$, $\left.\mathrm{CHCl}_{3}\right) .{ }^{1} \mathrm{H} \mathrm{NMR}\left(400 \mathrm{MHz}, \mathrm{CDCl}_{3}\right) \delta 8.22(\mathrm{~d}, J=8.8 \mathrm{~Hz}$, $2 \mathrm{H}), 8.04(\mathrm{~d}, J=8.8 \mathrm{~Hz}, 2 \mathrm{H}), 7.74(\mathrm{~d}, J=8.2 \mathrm{~Hz}, 2 \mathrm{H}), 7.26(\mathrm{~d}$, $J=8.2 \mathrm{~Hz}, 2 \mathrm{H}), 7.20(\mathrm{~s}, 1 \mathrm{H}), 7.15(\mathrm{~m}, 2 \mathrm{H}), 6.89(\mathrm{~d}, J=8.1 \mathrm{~Hz}$, $1 \mathrm{H}), 6.71(\mathrm{~d}, J=2.0 \mathrm{~Hz}, 1 \mathrm{H}), 6.67(\mathrm{dd}, J=8.1$ and $2.0 \mathrm{~Hz}$, $1 \mathrm{H}), 6.25(\mathrm{~d}, J=4.4 \mathrm{~Hz}, 1 \mathrm{H}), 5.93(\mathrm{~m}, 1 \mathrm{H}), 5.07(\mathrm{~s}, 1 \mathrm{H}), 5.05$ $(\mathrm{m}, 1 \mathrm{H}), 4.74(\mathrm{~m}, 1 \mathrm{H}), 3.87(\mathrm{dd}, J=10.6$ and $5.2 \mathrm{~Hz}, 1 \mathrm{H})$, $3.75(\mathrm{~s}, 3 \mathrm{H}), 3.62-3.55$ (complex m, 4H), $3.32(\mathrm{~d}, J=7.0 \mathrm{~Hz}$, $2 \mathrm{H}), 2.42(\mathrm{~s}, 3 \mathrm{H}), 0.89(\mathrm{~s}, 9 \mathrm{H}), 0.02(\mathrm{~s}, 6 \mathrm{H}) ;{ }^{13} \mathrm{C}$ NMR $(100$ $\left.\mathrm{MHz}, \mathrm{CDCl}_{3}\right) \delta 163.6,151.7,150.7,150.6,146.4,145.1,138.6$, $137.5,135.9,135.5,135.1,133.5,130.9,129.5,128.7,123.7$, 123.6, 120.8(3), 120.7(7), 118.3, 116.0, 113.4, 113.1, 81.7, 76.4, 61.9, 55.9, 55.8, 40.0, 26.0, 21.8, 18.3, -5.2(9), -5.3(4); IR $\nu_{\max }$ $2930,2856,1728,1602,1527,1505,1464,1373,1261,1177$, $1155,1091,1034,835,813,780,750,717 \mathrm{~cm}^{-1}$; MS (ESI, +ve) $\mathrm{m} / z 800(100)[\mathrm{M}+\mathrm{Na}]^{+} ; \mathrm{HRMS}$ calcd for $\mathrm{C}_{40} \mathrm{H}_{47} \mathrm{NNaO}_{11} \mathrm{SSi}$ $[\mathrm{M}+\mathrm{Na}]^{+}:$: 800.2537, found: 800.2537 .

$(1 R, 2 S)-2-(4-A l l y l-2-m e t h o x y p h e n o x y)-3-((t e r t-$ butyldimethylsilyl)oxy)-1-(3-methoxy-4-(tosyloxy)phenyl)propyl 4-Nitrobenzoate (ent-21). Treatment of compound ent-20 with $p$-nitrobenzoic acid, $\mathrm{Ph}_{3} \mathrm{P}$, and DEAD in the same manner as that described above gave ester ent-21 $(256 \mathrm{mg}$, $82 \%)$ as a white, crystalline solid, $[\alpha]^{20}{ }_{D}=+4.3(c=1.1$, $\mathrm{CHCl}_{3}$ ). All other spectral data acquired on this material were identical with those reported above for compound 21.

4-((1S,2R)-2-(4-Allyl-2-methoxyphenoxy)-3-((tertbutyldimethylsilyl)oxy)-1-hydroxypropy-I)-2-methoxyphenyl 4-Methylbenzenesulfonate (22). A magnetically stirred solution of $p$-nitrobenzoate $21(569 \mathrm{mg}, 0.73 \mathrm{mmol})$ in THF $(10 \mathrm{~mL})$ maintained at $0{ }^{\circ} \mathrm{C}$ under a nitrogen atmosphere was treated with $\mathrm{NaOH}$ ( $5 \mathrm{~mL}$ of a $1 \mathrm{M}$ aqueous solution, $5 \mathrm{mmol}$ ). The ensuing mixture was stirred at $0{ }^{\circ} \mathrm{C}$ for $0.5 \mathrm{~h}$ then warmed to $22{ }^{\circ} \mathrm{C}$, and after $0.5 \mathrm{~h}$, diluted with ethyl acetate $(50 \mathrm{~mL})$. The separated organic layer was washed with $\mathrm{NaHCO}_{3}(2 \times 10$ $\mathrm{mL}$ ), and the combined aqueous washings were extracted with ethyl acetate $(2 \times 10 \mathrm{~mL})$. The combined organic phases were washed with brine $(2 \times 15 \mathrm{~mL})$ before being dried $\left(\mathrm{Na}_{2} \mathrm{SO}_{4}\right)$, filtered, and concentrated under reduced pressure. The resulting yellow oil was subjected to flash column chromatography (silica, 1:49 v/ $\mathrm{vEt}_{2} \mathrm{O} /$ dichloromethane), and concentration of the appropriate fractions $\left(R_{\mathrm{f}}=0.3\right.$ in $1: 49 \mathrm{v} / \mathrm{v} \mathrm{Et}_{2} \mathrm{O} /$ DCM) afforded alcohol $22(340 \mathrm{mg}, 74 \%)$ as a clear, colorless oil, $[\alpha]^{20}{ }_{\mathrm{D}}=-8.0\left(c=0.9, \mathrm{CHCl}_{3}\right) .{ }^{1} \mathrm{H}$ NMR $(400 \mathrm{MHz}$, $\left.\mathrm{CDCl}_{3}\right) \delta 7.71(\mathrm{~d}, J=8.3 \mathrm{~Hz}, 2 \mathrm{H}), 7.26$ (partially obscured d, $J$ $=8.3 \mathrm{~Hz}, 2 \mathrm{H}), 7.10(\mathrm{~d}, J=8.3 \mathrm{~Hz}, 1 \mathrm{H}), 6.98(\mathrm{~d}, J=1.9 \mathrm{~Hz}$, $1 \mathrm{H}), 6.89(\mathrm{~s}, 1 \mathrm{H}), 6.87(\mathrm{~s}, 1 \mathrm{H}), 6.72(\mathrm{~m}, 2 \mathrm{H}), 5.95(\mathrm{~m}, 1 \mathrm{H})$, $5.10(\mathrm{~m}, 1 \mathrm{H}), 5.06(\mathrm{~s}, 1 \mathrm{H}), 4.92(\mathrm{t}, J=4.7 \mathrm{~Hz}, 1 \mathrm{H}), 4.26(\mathrm{~d}, J=$ $4.9 \mathrm{~Hz}, 1 \mathrm{H}), 4.17(\mathrm{~m}, 1 \mathrm{H}), 3.84(\mathrm{~s}, 3 \mathrm{H}), 3.83$ (partially obscured $\mathrm{m}, 1 \mathrm{H}), 3.63(\mathrm{dd}, J=11.0$ and $5.1 \mathrm{~Hz}, 1 \mathrm{H}), 3.52(\mathrm{~s}$, $3 \mathrm{H}), 3.34(\mathrm{~d}, J=6.8 \mathrm{~Hz}, 1 \mathrm{H}), 2.42(\mathrm{~s}, 3 \mathrm{H}), 0.88(\mathrm{~s}, 9 \mathrm{H}), 0.03$ $(\mathrm{s}, 3 \mathrm{H}), 0.02(\mathrm{~s}, 3 \mathrm{H})$ (signal due to the hydroxyl group proton not observed); ${ }^{13} \mathrm{C}$ NMR (100 MHz, $\left.\mathrm{CDCl}_{3}\right) \delta 151.7,151.3$, 145.6, 145.0, 140.7, 137.7, 137.4, 135.9, 133.4, 129.4, 128.8, $123.7,121.3,120.5,118.9,116.1,112.7,111.2,85.5,73.8,62.6$, 56.0, 55.6, 40.1, 26.0, 21.8, 18.3, -5.3, -5.4; IR $\nu_{\max } 3473$, 2952, 2930, 2856, 1600, 1505, 1463, 1418, 1373, 1262, 1175, 1117 1090, 1034, 836, 777, 716, $662 \mathrm{~cm}^{-1}$; MS (ESI, +ve) $\mathrm{m} / z$ $651(100)[\mathrm{M}+\mathrm{Na}]^{+}$; HRMS calcd for $\mathrm{C}_{33} \mathrm{H}_{44} \mathrm{NaO}_{8} \mathrm{SSi}[\mathrm{M}+$ $\mathrm{Na}]^{+}:$651.2424, found: 651.2424 .

4-((1R,2S)-2-(4-Allyl-2-methoxyphenoxy)-3-((tertbutyldimethylsilyl)oxy)-1-hydroxypropy-l)-2-methoxyphenyl 4-Methylbenzenesulfonate (ent-22). Treatment of ester ent21 with $\mathrm{NaOH}$ in THF in the same manner as that described immediately above gave alcohol ent-22 $(171 \mathrm{mg}, 83 \%)$ as a clear, colorless oil, $[\alpha]^{20}{ }_{\mathrm{D}}=+7.5\left(c=0.6, \mathrm{CHCl}_{3}\right)$. All other spectral data acquired on this material were identical with those reported above for compound 22 .

(E)-3-(4-(((1S,2R)-3-((tert-Butyldimethylsilyl)oxy)-1-hydroxy-1-(3-methoxy-4-(tosyloxy)-phenyl)propan-2-yl)oxy)-3methoxyphenyl)allyl Acetate (23). Acetic acid $(85 \mu \mathrm{L}, 1.5$ $\mathrm{mmol})$, sodium acetate $(1.5 \mathrm{mg}, 0.02 \mathrm{mmol})$, molecular sieves ( $2 \mathrm{mg}$ of activated $4 \AA$ material), 4,5-DAF $(1.2 \mathrm{mg}, 8 \mathrm{~mol} \%)$, and $\mathrm{Pd}(\mathrm{OAc})_{2}(1.5 \mathrm{mg}, 8 \mathrm{~mol} \%)$ were added, sequentially, to a magnetically stirred solution of alkene $22(48 \mathrm{mg}, 0.076 \mathrm{mmol})$ in 1,4-dioxane $(800 \mu \mathrm{L})$ maintained at $22{ }^{\circ} \mathrm{C}$. Oxygen from a balloon was gently bubbled through the reaction mixture for $0.25 \mathrm{~h}$, then the solution was heated at $60{ }^{\circ} \mathrm{C}$ with vigorous stirring under an atmosphere of oxygen. After $66 \mathrm{~h}$, the reaction mixture was cooled to $22{ }^{\circ} \mathrm{C}$, and the solvent was removed under reduced pressure. The ensuing black residue was subjected to flash column chromatography (silica, hexane $\rightarrow$ $3: 2 \mathrm{v} / \mathrm{v}$ ethyl acetate/hexane gradient elution), and concentration of the appropriate fractions $\left(R_{\mathrm{f}}=0.3\right.$ in $1: 1 \mathrm{v} / \mathrm{v}$ ethyl acetate/hexane) afforded ester $23(33 \mathrm{mg}, 64 \%)$ as a clear, colorless oil, $[\alpha]^{20}{ }_{\mathrm{D}}=-18.6\left(c=0.7, \mathrm{CHCl}_{3}\right) .{ }^{1} \mathrm{H}$ NMR $(400$ $\left.\mathrm{MHz}, \mathrm{CDCl}_{3}\right) \delta 7.71(\mathrm{~d}, J=8.3 \mathrm{~Hz}, 2 \mathrm{H}), 7.24$ (partially obscured $\mathrm{m}, 2 \mathrm{H}), 7.10(\mathrm{~d}, J=8.3 \mathrm{~Hz}, 1 \mathrm{H}), 6.99(\mathrm{~m}, 1 \mathrm{H}), 6.93$ (s, 1H), 6.91-6.87 (complex m, 3H), $6.59(\mathrm{dt}, J=15.8$ and 1.1 $\mathrm{Hz}, 1 \mathrm{H}), 6.19(\mathrm{dt}, J=15.8$ and $6.5 \mathrm{~Hz}, 1 \mathrm{H}), 4.93(\mathrm{t}, J=4.8 \mathrm{~Hz}$, $1 \mathrm{H}), 4.71(\mathrm{dd}, J=6.5$ and $1.1 \mathrm{~Hz}, 2 \mathrm{H}), 4.23(\mathrm{~m}, 1 \mathrm{H}), 4.10(\mathrm{~d}, J$ $=4.8 \mathrm{~Hz}, 1 \mathrm{H}), 3.86(\mathrm{~s}, 3 \mathrm{H}), 3.83$ (partially obscured $\mathrm{m}, 1 \mathrm{H})$, $3.68(\mathrm{~m}, 1 \mathrm{H}), 3.53(\mathrm{~s}, 3 \mathrm{H}), 2.42(\mathrm{~s}, 3 \mathrm{H}), 2.10(\mathrm{~s}, 3 \mathrm{H}), 0.88(\mathrm{~s}$, $9 \mathrm{H}), 0.03(\mathrm{~s}, 3 \mathrm{H}), 0.02(\mathrm{~s}, 3 \mathrm{H}) ;{ }^{13} \mathrm{C} \mathrm{NMR}\left(100 \mathrm{MHz}, \mathrm{CDCl}_{3}\right)$ $\delta 171.0,151.7,151.3,147.5,145.0,140.6,137.7,134.0,133.3$, $131.9,129.4,128.8,123.7,122.5,120.2,119.7,118.9,111.2$, $110.1,85.0,74.0,65.2,62.6,56.0,55.6,26.0,21.8,21.2,18.3$, $-5.3,-5.4$; IR $\nu_{\max } 3475,2932,2856,1737,1600,1506,1464$, 1418, 1372, 1251, 1229, 1175, 1117, 1091, 1031, 964, 837, 752, 716, $662 \mathrm{~cm}^{-1}$; MS (ESI, +ve) $\mathrm{m} / z 709(100)[\mathrm{M}+\mathrm{Na}]^{+}$; HRMS calcd for $\mathrm{C}_{35} \mathrm{H}_{46} \mathrm{NaO}_{10} \mathrm{SSi}[\mathrm{M}+\mathrm{Na}]^{+}:$: 09.2479 , found: 709.2478 . 
(E)-3-(4-(((1R,2S)-3-((tert-Butyldimethylsilyl)oxy)-1-hydroxy-1-(3-methoxy-4-(tosyloxy)-phenyl)propan-2-yl)oxy)-3methoxyphenyl)allyl Acetate (ent-23). Oxidation of alkene ent-22 in an analogous fashion to that described immediately above gave acetate ent-23 (67 mg, 33\%) as a clear, colorless oil, $[\alpha]_{\mathrm{D}}^{20}=+17.7\left(c=1, \mathrm{CHCl}_{3}\right)$. All other spectral data acquired on this material were identical with those reported above for compound 23.

(1S,2R)-1-(4-Hydroxy-3-methoxyphenyl)-2-(4-((E)-3-hydroxyprop-1-en-1-yl)-2-methoxyp-henoxy)propane-1,3-diol (ent-2). TBAF $x \mathrm{H}_{2} \mathrm{O}(37 \mathrm{mg}$, ca. $0.12 \mathrm{mmol})$ was added in one portion to a magnetically stirred solution of acetate $23(55 \mathrm{mg}$, $0.080 \mathrm{mmol})$ in THF $(3 \mathrm{~mL})$ maintained at $22{ }^{\circ} \mathrm{C}$ under a nitrogen atmosphere. After $1 \mathrm{~h}$, the reaction mixture was treated with methanol $(3 \mathrm{~mL})$ then $\mathrm{NaOH}(1 \mathrm{~mL}$ of a $3 \mathrm{M}$ aqueous solution, $3 \mathrm{mmol}$ ) before being heated at $80{ }^{\circ} \mathrm{C}$. After $3 \mathrm{~h}$, the reaction mixture was cooled to $22^{\circ} \mathrm{C}$, acidified to $\mathrm{pH} 5$ using acetic acid, then diluted with ethyl acetate $(15 \mathrm{~mL})$. The separated organic phase was washed with brine $(3 \times 5 \mathrm{~mL}$ of a ca. 13 wt $\%$ solution), and the combined aqueous washings were extracted with ethyl acetate $(3 \times 5 \mathrm{~mL})$. The combined organic phases were washed with brine $(1 \times 5 \mathrm{~mL}$ of a ca. $13 \mathrm{wt}$ $\%$ solution) before being dried $\left(\mathrm{Na}_{2} \mathrm{SO}_{4}\right)$, filtered, and concentrated under reduced pressure. The ensuing pale-yellow residue was subjected to flash column chromatography (silica, $1: 19 \mathrm{v} / \mathrm{v}$ methanol/dichloromethane $\rightarrow 1: 9 \mathrm{v} / \mathrm{v}$ methanol/ dichloromethane gradient elution), and concentration of the appropriate fractions $\left(R_{\mathrm{f}}=0.5\right.$ in $1: 9 \mathrm{v} / \mathrm{v}$ methanol/dichloromethane) afforded compound ent-2 $(22 \mathrm{mg}, 73 \%)$ as a clear, colorless gum, $[\alpha]^{20}{ }_{\mathrm{D}}=-8.2(c=1.1$, methanol $) .{ }^{1} \mathrm{H}$ NMR $\left(400 \mathrm{MHz}, \mathrm{CD}_{3} \mathrm{OD}\right) \delta 7.02(\mathrm{~d}, J=1.9 \mathrm{~Hz}, 1 \mathrm{H}), 6.99$ (broad s, $1 \mathrm{H}), 6.88-6.86$ (complex m, $2 \mathrm{H}), 6.84(\mathrm{dd}, J=8.1$ and $1.9 \mathrm{~Hz}$, $1 \mathrm{H}), 6.73(\mathrm{~d}, J=8.1 \mathrm{~Hz}, 1 \mathrm{H}), 6.51(\mathrm{dt}, J=15.9$ and $1.5 \mathrm{~Hz}$, $1 \mathrm{H}), 6.23(\mathrm{dt}, J=15.8$ and $5.8 \mathrm{~Hz}, 1 \mathrm{H}), 4.83(\mathrm{~d}, J=5.8 \mathrm{~Hz}$, $1 \mathrm{H}$ ), 4.36 (ddd, $J=5.8,5.7$ and $3.7 \mathrm{~Hz}, 1 \mathrm{H}), 4.19(\mathrm{dd}, J=5.8$ and $1.5 \mathrm{~Hz}, 2 \mathrm{H}), 3.85(\mathrm{dd}, J=12.0$ and $5.7 \mathrm{~Hz}, 1 \mathrm{H}), 3.80(\mathrm{~s}$, $3 \mathrm{H}), 3.77(\mathrm{dd}, J=12.0$ and $3.7 \mathrm{~Hz}, 1 \mathrm{H}) ;{ }^{13} \mathrm{C} \mathrm{NMR}(100 \mathrm{MHz}$, $\left.\mathrm{CD}_{3} \mathrm{OD}\right) \delta 151.9,148.9,148.7,147.0,134.1,133.0,131.4$, 128.5, 121.0, 120.6, 118.9, 115.6, 111.9, 111.4, 86.2, 74.1, 63.7, 62.2, 56.5, 56.3; IR $\nu_{\max } 3345,2937,1602,1509,1463,1264$, 1128, 1028, $968 \mathrm{~cm}^{-1}$; MS (ESI, +ve) $\mathrm{m} / z 399$ (100) $[\mathrm{M}+$ $\mathrm{Na}]^{+}$; HRMS calcd for $\mathrm{C}_{20} \mathrm{H}_{24} \mathrm{NaO}_{7}[\mathrm{M}+\mathrm{Na}]^{+}$: 399.1420, found: 399.1419; HPLC analysis: Chiracel AS-H column, 85:15 $\mathrm{v} / \mathrm{v} n$-hexane/ethanol elution, flow rate $1.0 \mathrm{~mL} / \mathrm{min}$, detection at $\lambda=254 \mathrm{~nm}, t=35.8 \mathrm{~min}$, ee $>99 \%$.

(1R,2S)-1-(4-Hydroxy-3-methoxyphenyl)-2-(4-((E)-3-hydroxyprop-1-en-1-yl)-2-methoxyp-henoxy)propane-1,3-diol (2). Treatment of compound ent-23 with TBAF then aqueous sodium hydroxide in an analogous fashion to that described immediately above gave compound $2^{9 \mathrm{k}}(6.8 \mathrm{mg}, 73 \%)$ as a clear, colorless gum, $[\alpha]_{\mathrm{D}}^{20}=+7.4(c=0.5$, methanol $)\left\{\right.$ lit. $^{9 \mathrm{k}}$ $\left.[\alpha]_{\mathrm{D}}^{20}=+10.8\left(c=1, \mathrm{CHCl}_{3}\right)\right\} .{ }^{1} \mathrm{H}$ NMR $[600 \mathrm{MHz}$, $\left.\left(\mathrm{CD}_{3}\right)_{2} \mathrm{SO}\right] \delta 8.71(\mathrm{~s}, 1 \mathrm{H}), 6.99(\mathrm{~m}, 2 \mathrm{H}), 6.91(\mathrm{~d}, J=8.4 \mathrm{~Hz}$, $1 \mathrm{H}), 6.83(\mathrm{dd}, J=8.4$ and $2.0 \mathrm{~Hz}, 1 \mathrm{H}), 6.72(\mathrm{~m}, 2 \mathrm{H}), 6.43(\mathrm{dt}$, $J=15.9$ and $1.9 \mathrm{~Hz}, 1 \mathrm{H}), 6.22(\mathrm{dt}, J=15.9$ and $5.5 \mathrm{~Hz}, 1 \mathrm{H})$, $5.27(\mathrm{~d}, J=4.7 \mathrm{~Hz}, 1 \mathrm{H}), 4.75$ (app. $\mathrm{t}, J=5.6 \mathrm{~Hz}, 1 \mathrm{H}), 4.70$ (app. t, $J=4.9 \mathrm{~Hz}, 1 \mathrm{H}), 4.56$ (app. t, $J=5.6 \mathrm{~Hz}, 1 \mathrm{H}), 4.29(\mathrm{~m}$, $1 \mathrm{H}), 4.08(\mathrm{~m}, 2 \mathrm{H}), 3.73(\mathrm{~s}, 3 \mathrm{H}), 3.72(\mathrm{~s}, 3 \mathrm{H}), 3.60(\mathrm{~m}, 2 \mathrm{H})$; ${ }^{13} \mathrm{C}$ NMR $\left[150 \mathrm{MHz},\left(\mathrm{CD}_{3}\right)_{2} \mathrm{SO}\right] \delta 149.6,147.4,146.8,145.3$, $133.0,129.9,128.4,128.3,119.3,118.8,115.5,114.4,111.3$, $109.8,83.6,71.5,61.4,60.0,55.5,55.3$. These spectral data matched those reported by Nair and co-workers. ${ }^{9 \mathrm{k}}$ All other spectral data acquired on this material were identical with those reported above for compound ent-2. HPLC analysis: Chiracel AS-H column, $85: 15 \mathrm{v} / \mathrm{v} n$-hexane/ethanol elution, flow rate $1.0 \mathrm{~mL} / \mathrm{min}$, detection at $\lambda=254 \mathrm{~nm}, t=43.2 \mathrm{~min}$, ee $>99 \%$.

Endothelial Cell Tubule Formation Assay. Human microvascular endothelial cells (HMECs) were grown in MCDB131 media supplemented with $10 \%$ fetal bovine serum (FBS), hydrocortisone $(500 \mu \mathrm{g} / \mathrm{mL})$, epidermal growth factor $(0.01 \mathrm{mg} / \mathrm{mL})$, L-glutamine $(2 \mathrm{mM})$, and antibiotics. At $80-$ $90 \%$ confluency, the cells were trypsinized, pelleted by centrifugation, and resuspended in MCDB131 medium containing $0.2 \%$ FBS at $4 \times 10^{5} / \mathrm{mL}$ cell density. One $\mathrm{mL}$ of the cell suspension was then transferred to microfuge tubes and incubated with $30 \mu \mathrm{M}$ PD98059 for $0.5 \mathrm{~h}$ at room temperature prior to the addition of $12.5 \mathrm{ng} / \mathrm{mL}$ FGF-2 or $0.1 \mu \mathrm{M}$ of each of the compounds 1, ent-1, 2, and ent-2 (final concentrations). Alternately, $1 \mathrm{~mL}$ of cell suspension was incubated with FGF-2 alone $(12.5 \mathrm{ng} / \mathrm{mL})$ or each neolignan $(0.1 \mu \mathrm{M})$. The suspensions were gently mixed (pipetting up and down three times), and $100 \mu \mathrm{L}\left(4 \times 10^{4}\right.$ cells $)$ was aliquoted into a 96 well plate that had been pre-coated overnight at $4{ }^{\circ} \mathrm{C}$ with Matrigel basement membrane matrix. The plates were incubated at 37 ${ }^{\circ} \mathrm{C}$, and the cells in each well were photographed (under $40 \times$ magnification) $4 \mathrm{~h}$ after seeding. Microtubules were counted using Image $\mathrm{J}$ software. Each treatment was performed in triplicate, and four independent experiments were performed.

\section{ASSOCIATED CONTENT}

Supporting Information

The Supporting Information is available free of charge on the ACS Publications website at DOI: 10.1021/acsomega.7b01459.

${ }^{1} \mathrm{H}$ and ${ }^{13} \mathrm{C}$ NMR spectra of compounds $( \pm)-\mathbf{1}, \mathbf{1}$, ent-1, (士)-2, 2, ent-2, 4-7 (and precursors), 9, 10, 14, 15, 17 (and precursor), 18-23 and ${ }^{1} \mathrm{H}$ NMR spectra of compounds ent-15, ent-17 (and precursor), and ent18-ent-23 (PDF)

\section{AUTHOR INFORMATION}

\section{Corresponding Author}

*E-mail: Martin.Banwell@anu.edu.au.

ORCID

Martin G. Banwell: 0000-0002-0582-475X

Notes

The authors declare no competing financial interest.

\section{ACKNOWLEDGMENTS}

We thank the National Health and Medical Research Council, the Australian Research Council, and the Institute of Advanced Studies for financial support. J.N.B. is the grateful recipient of a Ph.D. Scholarship provided by the Australian Government. Dr. Hideki Onagi is thanked for assistance with chiral HPLC analyses. L.M.K. is a NH\&MRC Australia Fellow.

\section{ADDITIONAL NOTE}

${ }^{1}$ It is also possible that the conversion $7+8 \rightarrow 9$ proceeds via an $\mathrm{S}_{\mathrm{N}} 1$ pathway.

\section{REFERENCES}

(1) See, for example (a) Bouïs, D.; Kusumanto, Y.; Meijer, C.; Mulder, N. H.; Hospers, G. A. P. Pharmacol. Res. 2006, 53, 89. (b) Huang, D.; Lan, H.; Liu, F.; Wang, S.; Chen, X.; Jin, K.; Mou, X. Int. J. Clin. Exp. Med. 2015, 8, 8369. (c) Ernens, I.; Bousquenaund, M.; Lenoir, B.; Devaux, Y.; D. R. Wagner, L. J. Leukocyte Biol. 2015, 97, 10. 
(2) See, for example (a) Majewska, I.; Gendaszewska-Darmach, E. Acta Biochim. Pol. 2011, 58, 449. (b) Zhang, Z.-R.; Li, J.-H.; Li, S.; Liu, A.-L.; Hoi, P.-M.; Tain, H.-Y.; Ye, W.-C.; Lee, S. M.-Y.; Jiang, R.-W. PLoS One 2014, 9, No. e100416. (c) Zeng, Z.; Zhu, B.-H. J. Ethnopharmacol. 2014, 154, 653. (d) Lee, J.; Kim, M.; Kim, J. H. Nat. Prod. Sci. 2016, 22, 287. (e) Ishimoto, Y.; Hirota-Takahata, Y.; Kurosawa, E.; Chiba, J.; Iwadate, Y.; Onozawa, Y.; Hasegawa, T.; Tamura, A.; Tanaka, M.; Kobayashi, H. Cell. Physiol. Biochem. 2016, 39, 1905. (f) Li, L.; Liu, N.; Dai, X.; Yan, H.; Zhang, L.; Xing, L.; Wang, Y.; Wang, Y. RSC Adv. 2016, 6, No. 115308.

(3) Kordbacheh, F.; Carruthers, T. J.; Bezos, A.; Oakes, M.; Du Fall, L.; Hocart, C. H.; Parish, C. R.; Djordjevic, M. A. PLoS One, submitted for publication.

(4) (a) Gellerstedt, G.; Lundquist, K.; Wallis, A. F. A.; Zhang, L. Phytochemistry 1995, 40, 263. (b) Li, S.; Lundquist, K.; Wallis, A. F. A. Phytochemistry 1998, 49, 2125. (c) Cutillo, F.; D’Abrosca, B.; DellaGreca, M.; Fiorentino, A.; Zarrelli, A. J. Agric. Food Chem. 2003, 51, 6165. (d) Han, H.-Y.; Wang, X.-H.; Wang, N.-L.; Ling, M.T.; Wong, Y.-C.; Yao, X.-S. J. Agric. Food Chem. 2008, 56, 6928. (e) Li, L.; Seeram, N. P. J. Agric. Food Chem. 2010, 58, 11673. (f) Jeong, E. J.; Cho, J. H.; Sung, S. H.; Kim, S. Y.; Kim, Y. C. Bioorg. Med. Chem. Lett. 2011, 21, 2283. (g) Yang, J.-H.; Kondratyuk, T. P.; Jermihov, K. C.; Marler, L. E.; Qium, X.; Choi, Y.; Cao, H.; Yu, R.; Sturdy, M.; Huang, R.; Liu, Y.; Wang, L.-Q.; Mesecar, A. D.; van Breeman, R. B.; Pezzuto, J. M.; Fong, H. H. S.; Chen, Y.-G.; Zhang, H.-J. J. Nat. Prod. 2011, 74, 129. (h) Xiong, J.; Bui, V.-B.; Liu, X.-H.; Hong, Z.-L.; Yang, G.-X.; Hum, J.-F. J. Ethnopharmacol. 2014, 153, 737. (i) Liu, Q.-B.; Huang, X.-X.; Yan, X.-J.; Bai, M.; Yu, L.-H.; Hu, C.; Zhu, T.; Li, L.-Z.; Song, S.J. Biochem. Syst. Ecol. 2014, 55, 236. (j) Wang, L.; Liu, F.; Yang, C.-Y.; Khan, A.-A.; Liu, X.; Wang, M.-K. Fitoterapia 2014, 99, 92. (k) Huang, X.-X.; Liu, Q.-B.; Zhou, L.; Liu, S.; Cheng, Z.-Y.; Sun, Q.; Li, L.-Z.; Song, S.-J. Rec. Nat. Prod. 2015, 9, 305. (1) Woo, K. W.; Suh, W. S.; Subedi, L.; Kim, S. Y.; Kim, A.; Lee, K. R. Bioorg. Med. Chem. Lett. 2016, 26, 730 .

(5) (a) Katayama, T.; Kado, Y. J. Wood Sci. 1998, 44, 244. (b) Syrjänen, K.; Sipilä, J.; Björk, H.; Brunow, G. J. Agric. Food Chem. 2000, 48, 5211. (c) Syrjänen, K.; Brunow, G. Tetrahedron 2001, 57, 365. (d) Fournand, D.; Lapierre, C. J. Agric. Food Chem. 2001, 49, 5727. (e) Fournand, D.; Cathala, B.; Lapierre, C. Phytochemistry 2003, 62, 139. (f) Raiskila, S.; Fagerstedt, K.; Laakso, T.; Saranpää, P.; Löija, M.; Paajanen, L.; Mahlberg, R.; Ritschkoff, A.-C. Wood Sci. Technol. 2006, 40, 697. (g) Russell, W. R.; Burkitt, M. J.; Scobbie, L.; Chesson, A. Biomacromolecules 2006, 7, 268. (h) Wan, Y.; Lu, R; Akiyama, K.; Miyakoshi, T.; Du, Y. Sci. China, Ser. B: Chem. 2007, 50, 179. (i) Matsushita, Y.; Ko, C.; Aoki, D.; Hashigaya, S.; Yagami, S.; Fukushima, K. J. Wood Sci. 2015, 61, 608.

(6) For a definitive commentary on the nomenclature that applies to the lignans and neolignans see Moss, G. P. Pure Appl. Chem. 2000, 72, 1493.

(7) For a recent review on lignans and neolignans see Teponno, $R$. B.; Kusari, S.; Spiteller, M. Nat. Prod. Rep. 2016, 33, 1044.

(8) For a useful introduction to this topic see Sefkow, M. Synthesis 2003, 17, 2595.

(9) (a) Lee, A.-L.; Ley, S. V. Org. Biomol. Chem. 2003, 1, 3957. (b) Chen, X.-C.; Ren, X. F.; Peng, K.; Wu, T.-X.; Pan, X.-F. Chem. J. Chin. Univ. 2003, 24, 1811. (c) Ren, X.; She, X.; Peng, K.; Su, Y.; Xie, X.; Pan, X.; Zhang, H. J. Chin. Chem. Soc. 2004, 51, 969. (d) Curti, C.; Zanardi, F.; Battistini, L.; Sartori, A.; Rassu, G.; Pinna, L.; Casiraghi, G. J. Org. Chem. 2006, 71, 8552. (e) Xia, Y. M.; Wang, W.; Guo, Y.-L.; Li, J.-F. Turk. J. Chem. 2010, 34, 375. (f) Ding, J.; Qi, R.; Zhou, H.; Jiao, B.; Xia, Y. J. Chem. Res. 2011, 35, 519. (g) Xia, Y.; Wang, W. Monatsh. Chem. 2011, 142, 93. (h) Nagaraju, M.; Chandra, R.; Gawali, B. B. Synlett. 2012, 23, 1485. (i) Bernal, F. A.; Cuca, L. E.; Fadini, L. Rev. Fac. Cienc. Basicas 2015, 11, 114. (j) Gangar, M.; Chouhan, M.; Goyal, S.; Harikrishnan, M.; Chandran, R.; Ittuveetil, A.; Nair, V. A. Tetrahedron Lett. 2016, 57, 5931. (k) Gangar, M.; Ittuveetil, A.; Goyal, S.; Pal, A.; Harikrishnan, M.; Nair, V. A. RSC Adv. 2016, 6, No. 102116.
(10) For other relevant synthetic studies see Lourith, N.; Katayama, T.; Suzuki, T. J. Wood Sci. 2005, 51, 370.

(11) Sharpless, K. B.; Amberg, W.; Bennani, Y. L.; Crispino, G. A.; Hartung, J.; Jeong, K.-S.; Kwong, H.-L.; Morikawa, K.; Wang, Z.-M.; Xu, D.; Zhang, X.-L. J. Org. Chem. 1992, 57, 2768.

(12) Peng, K.; Chen, F.; She, X.; Yang, C.; Cui, Y.; Pan, X. Tetrahedron Lett. 2005, 46, 1217.

(13) Gage, J. R.; Evans, D. A. Org. Synth. 1990, 68, 83 and references cited therein.

(14) (a) Hinterman, T.; Seebach, D. Helv. Chim. Acta 1998, 81, 2093. (b) Brenner, M.; La Vecchia, L.; Leutert, T.; Seebach, D. Org. Synth. 2003, 80, 57.

(15) Campbell, A. N.; White, P. B.; Guzei, I. A.; Stahl, S. S. J. Am. Chem. Soc. 2010, 132, 15116.

(16) Brown, R. F. C.; Jackson, W. R.; McCarthy, T. D. Tetrahedron Lett. 1993, 34, 1195.

(17) Arnaoutova, I.; George, J.; Kleinman, H. K.; Benton, G. Angiogenesis 2009, 12, 267.

(18) Folkman, J.; Klagsbrun, M.; Sasse, J.; Wadzinski, M.; Ingber, D.; Vlodavsky, I. Am. J. Pathol. 1988, 130, 393.

(19) Still, W. C.; Kahn, M.; Mitra, A. J. Org. Chem. 1978, 43, 2923.

(20) Pangborn, A. B.; Giardello, M. A.; Grubbs, R. H.; Rosen, R. K.; Timmers, F. J. Organometallics 1996, 15, 1518.

(21) Bazin, M.-A.; El, K. L.; Jouanne, M.; Lancelot, J.-C.; Rault, S. Synth. Commun. 2008, 38, 3947.

(22) Li, N.-G.; Shi, Z.-H.; Tang, Y.-P.; Li, B.-Q.; Duan, J.-A. Molecules 2009, 14, 2118.

(23) Liu, Z.; Lan, J.; Li, Y. Tetrahedron: Asymmetry 1998, 9, 3755.

(24) Jirásek, P.; Amslingerm, S.; Heilmann, J. J. Nat. Prod. 2014, 77, 2206.

(25) Spurg, A.; Waldvogel, S. R. Eur. J. Org. Chem. 2008, 2008, 337.

(26) Labarrios, F.; Garduño, L.; Del Rosariao Vidal, M.; Garcia, R.; Salazar, M.; Martinez, E.; Doax, F.; Chamorro, G.; Tamariz, J. J. Pharm. Pharmacol. 1999, 51, 1.

(27) Shirai, T.; Kumihashi, K.; Sakasai, M.; Kusuoku, H.; Shibuya, Y.; Ohuchi, A. ACS Med. Chem. Lett. 2017, 8, 715. 